\title{
RESURRECTING "A COMPREHENSIVE CHARTER OF ECONOMIC LIBERTY": THE LATENT POWER OF THE FEDERAL TRADE COMMISSION
}

\section{Sandeep Vaheesan*}

After decades of virtual invisibility, monopoly and oligopoly are attracting the attention of leading political and public figures again. Corporate control of markets is now seen as an important source of economic and political ills in American society. These ills include not just higher prices for consumers, but also increased economic inequality and a compromised democracy. This corporate domination of economy and politics was not inevitable, dictated by impersonal forces such as "globalization" or "technology." On the contrary, it is the result of conscious policy choices initiated in the late $1970 \mathrm{~s}$ and $1980 \mathrm{~s}$ that succeeded in focusing antitrust law on the narrow concept of economic efficiency and establishing legal standards friendly to powerful businesses. The weakened antitrust laws have given large corporations freedom to dominate markets through mergers, exclusionary conduct, and restrictive trade practices.

The Supreme Court has the power to undo these changes, but an antitrust revival through the common law process is doubtful and, at best, sure to be protracted. When favorable political circumstances exist, advocates of renewed antitrust enforcement should instead look to the Federal Trade Commission ("FTC"). The FTC has broad policymaking authority under modern administrative law and has quasi-legislative power delegated to it by Congress. The FTC can resurrect antitrust law under the FTC Act's prohibition on unfair methods of competition. In using this power, the FTC should reject the ahistorical efficiency model for antitrust and embrace the political economic goals articulated by Congress when it created the Commission in 1914. In an era of high inequality, diminished

\footnotetext{
* Regulations Counsel, Consumer Financial Protections Bureau. This Article reflects the views of the author alone and not necessarily those of the United States or Consumer Financial Protection Bureau. The author thanks Ken Davidson, Ben Douglas, Lina Khan, Frank Pasquale, Sabeel Rahman, Jason Rathod, Bob Skitol, Maurice Stucke, and Randy Stutz for their thoughtful feedback on earlier drafts of this Article and helpful input on developing the ideas in this Article.
} 
economic opportunity, and elite capture of politics, the goals of protecting consumers, maintaining open markets, and dispersing economic and political power remain as important as ever. To restore competitive market structures, the FTC should establish a series of presumptions against competitively suspicious practices and challenge market power highly damaging to the public.

INTRODUCTION

I. The FTC HAS the AUthority to DeFine the MEANING OF SECTION 5.

A. Modern Administrative Law Gives the FTC Broad Discretion to Interpret Section 5 .

B. Congress in 1914 Expressly Delegated Power to the FTC to Interpret Section 5

II. IN ENACTING THE FTC ACT, CONGRESS HAD AN EXPANSIVE VISION FOR

SECTION 5 .

A. Section 5 of the FTC Act Has a Multifaceted Political Economic Purpose.

B. Section 5 Is Intended to Be Broader than the Other Antitrust Laws.....

III. THE FTC's 2015 AFFIRMATION OF A LIMITED ANTITRUST THAT

CONTRAVENES CONGRESS' GOALS

A. The FTC Doubled Down on the Ahistorical Efficiency Paradigm....664

B. The FTC Endorsed a Legal Standard that Grants Powerful

Businesses Carte Blanche to Control Markets.

IV. How the FTC CAN HONOR CONGRESSIONAL INTENT AND RESTORE PROGRESSIVE-POPULIST ANTITRUST LAW

A. The FTC Should Anchor Section 5 in the Congressionally Expressed Goals of the Statute

B. The FTC Should Establish Presumptions Against Competitively Suspect Conduct.

C. The FTC Should Challenge Durable or Otherwise Seriously Harmful Monopolies and Oligopolies

D. The FTC Should Favor Simple Structural Remedies

V. RESPONDING TO LIKELY OBJECTIONS TO AN EXPANSIVE SECTION 5 .688

A. Attacking the Proposed Interpretation of Section 5 on Efficiency Grounds Ignores Congressional Intent.

B. Claiming that Proposed Section 5 Would Create Substantive Inconsistency Between the FTC and the DOJ Disregards Congressional Intent and Existing Antitrust Practice

C. Recognizing the Threat of Adverse Congressional Action Does Not Compel Continued Adherence to the Antitrust Status Quo 


\section{INTRODUCTION}

After decades of general neglect, ${ }^{1}$ monopoly and oligopoly are now a topic of wide interest in the United States. Corporate domination of wide swaths of the economy is a focus of public debate. ${ }^{2}$ This discussion is not confined to one part of the political spectrum. A progressive senator, ${ }^{3}$ the 2016 Democratic candidate for the presidency, ${ }^{4}$ the centrist Obama White House, ${ }^{5}$ and a conservative business publication ${ }^{6}$ have all agreed that the

1. See Maurice E. Stucke \& Allen P. Grunes, Big Data And Competition Policy 235-51 (2016) (providing statistics on declining U.S. antitrust enforcement since 1970, and the implications of weak enforcement in several industries); Maurice E. Stucke, Reconsidering Antitrust's Goals, 53 B.C. L. REV. 551, 553-54 (2012) (observing the lack of public interest in both antitrust specifically and economic concentration generally); see also Harry First \& Spencer Weber Waller, Antitrust's Democracy Deficit, 81 FoRDHAM L. REV. 2543, 2544 (2013) (describing the antitrust system as one "captured by lawyers and economists advancing their own self-referential goals, free of political control and economic accountability").

2. See Ryan Cooper, Even Republicans are Getting Fed Up with Monopolies. Here's Why., THE WEEK (Mar. 31, 2016), http://theweek.com/articles/613950/even-republicans-aregetting-fed-monopolies-heres-why [https://perma.cc/968Y-MELM] (“[T]oday, the results of monopoly are so patently horrible that even some conservatives are beginning to come around."); Paul Krugman, Challenging the Oligarchy, N.Y. REv. BoOKS (Dec. 17, 2015), http://www .nybooks.com/articles/2015/12/17robert-reich-challenging-oligarchy/

[https://perma.cc/5T77-TX3X] (describing an argument attributing increased economic inequality to monopolies); Matt Stoller, How Democrats Killed Their Populist Soul, ATLANTIC, Oct. 24, 2016, https://www.theatlantic.com/politics/archive/2016/10/howdemocrats-killed-their-populist-soul/504710/ ("At the same time that the nation has achieved perhaps the most tolerant culture in U.S. history, the destruction of the antimonopoly and anti-bank tradition in the Democratic Party has also cleared the way for the greatest concentration of economic power in a century.").

3. See Elizabeth Warren, Senator, Keynote Address at New America's Open Markets Program Event: Reigniting Competition in the American Economy, (June 29, 2016) (arguing that the lack of competition in the markets "threatens our economy, and threatens our democracy").

4. See Hillary Clinton, Hillary Clinton: Being Pro-Business Doesn't Mean Hanging Consumers Out to Dry, QuARTZ (Oct. 20, 2015), http://qz.com/529303/hillary-clintonbeing-pro-business-doesnt-mean-hanging-consumers-out-to-dry/ [https://perma.cc/5EZLJB2E] (describing the negative impacts of monopolies on American consumers).

5. See Council of ECON. Advisers, BENEFITS OF COMPETITION AND INDiCATORS OF MARKET POWER 4-6 (2016), https://www.whitehouse.gov/sites/default/files/page/files/ 20160414_cea_competition_issue_brief.pdf [https://perma.cc/C3CX-KQ3G] (detailing the proof of decline in competition).

6. See Too Much of a Good Thing, ECONOMIST (Mar. 26, 2016), http://www .economist.com/news/briefing/21695385-profits-are-too-high-america-needsgiant-dose-competition-too-much-good-thing [https://perma.cc/759G-FD59] (arguing that high profits indicate a need for competition). 
non-competitive structure of many markets hurts the public. The harms from concentrated markets appear to range from higher prices for consumer products $^{7}$ and lower incomes for producers ${ }^{8}$ to the multi-decade growth in inequality ${ }^{9}$ to the decline in business formation ${ }^{10}$ to the subversion of democratic politics by powerful private entities. ${ }^{11}$

Importantly, commentators have recognized that the current industrial structure in the United States was not inevitable. Present economic arrangements are the product of a deliberate policy choice-starting in the late 1970s and accelerating in the 1980s under the Reagan administrationto neuter the enforcement of the antitrust laws outside of price fixing, bid rigging and market allocation between competitors. ${ }^{12}$ Subsequent administrations, including Democratic ones, have followed this antitrust philosophy. ${ }^{13}$ Antitrust officials in the executive branch and federal judges

7. See, e.g., id. ("Last year America's airlines made \$24 billion-more than Alphabet, the parent company of Google. Even as the price of fuel, one of airlines' main expenses, collapsed alongside the oil price, little of that benefit was passed on to consumers through lower prices, with revenues remaining fairly flat. After a bout of consolidation in the past decade the industry is dominated by four firms with tight financial discipline and many shareholders in common. And the return on capital is similar to that seen in Silicon Valley.")

8. Ariel Ezrachi \& Maurice Stucke, The E-Scraper and E-Monopsony, AutHORS GuILD (Apr. 12, 2017), https://www .authorsguild .org/industry-advocacy/law-profs-antitrustenforcers-rein-super-platforms-look-upstream/ [https://perma.cc/SV8H-Q34R] (associating the decline in average income for authors to the growing monopsony power of Amazon over book publishers).

9. See, e.g., Jonathan B. Baker \& Steven C. Salop, Antitrust, Competition Policy, and Inequality, 104 GEO. L.J. ONLINE 1, 2 (2015) (offering statistics on the growth of inequality); Lina Khan \& Sandeep Vaheesan, Market Power and Inequality: The Antitrust Counterrevolution and Its Discontents, 11 HARV. L. \& POL'y REV. 235, 265 (2017) (stating that firms in concentrated markets, as opposed to competitive markets, can obtain political influence to support favorable policy).

10. See, e.g., Stacy Mitchell, The View from the Shop-Antitrust and the Decline of America's Independent Businesses, 61 ANTITRUST BULLETIN 498, 502 (2016) (noting the decrease in small businesses, and the corresponding increase in large corporations in government policy, from 1997-2012).

11. See, e.g., Warren, supra note 3 , at 3 ("The larger and more economically powerful these companies get, the more resources they can bring to bear on lobbying government to change the rules to benefit exactly the companies that are doing the lobbying. Over time, this means a closed, self-perpetuating, rigged system - a playing field that lavishes favors on the big guys, hammers the small guys, and fuels even more concentration.")

12. Warren, supra note 3, at 5-6; David Dayen, Bring Back Antitrust, THE AM. PROSPECT (Nov. 9, 2015), http://prospect.org/article/bring-back-antitrust-0 [https://perma.cc/356M-SMAZ]; Kevin Drum, Our Four-Decade Antitrust Experiment Has Failed, MoTHER JONES (Mar. 15, 2016), http://www.motherjones.com/kevin-drum/2016/03/ our-four-decade-antitrust-experiment-has-failed [https://perma.cc/2BQ7-VJV4].

13. See, e.g., U.S. DEP'T OF JUSTICE, ANTITRUST Division: WORKLOAD STATISTICS: FY 2006-2015 5-6 (2015), https://www.justice.gov/atr/file/788426/download 
have applied these laws to focus narrowly on the neoclassical concept of allocative efficiency and adopted defendant-friendly legal standards. ${ }^{14}$ This constricted focus contradicts the broad economic, political, and social purposes of antitrust laws. A body of law that could historically be characterized as "a comprehensive charter of economic liberty" 15 and "the Magna Carta of free enterprise" $"$ has been reduced to a technocratic field with limited reach.

While the courts could and should reinterpret the antitrust laws to accord with Congress's vision in 1890 and 1914 through the common law process, this judicial restoration, even under the best of circumstances, is sure to be a slow process. Given the conservative composition of the courts, in particular the Supreme Court, reinterpretation of the Sherman and Clayton Acts does not seem imminent. Many liberal judges have accepted, in large measure, the efficiency-oriented antitrust that has been dominant for nearly forty years. For example, Justice Breyer ${ }^{17}$ and even liberal icon Justice Brennan ${ }^{18}$ authored or joined notable opinions that advanced the project to curtail antitrust law. Even if President Obama had appointed Merrick Garland and established a liberal majority on the Supreme Court, the Court would likely not have ushered in an antitrust revival. ${ }^{19}$ And now with Justice Gorsuch succeeding Justice Scalia, ${ }^{20}$ the Supreme Court is

[https://perma.cc/EYB6-DLAL] (noting that from 2006 to 2015, the Bush and Obama administrations together filed just one monopolization suit, and the number of merger cases filed annually remained about the same).

14. See Eleanor M. Fox \& Lawrence A. Sullivan, Antitrust-Retrospective and Prospective: Where Are We Coming From? Where Are We Going?, 62 N.Y.U. L. Rev. 936 (1987) (detailing the development of the pro-defendant approaches of federal judges and executive branch officials).

15. N. Pac. Ry. Co. v. United States, 356 U.S. 1, 4 (1958).

16. United States v. Topco Assocs., Inc., 405 U.S. 596, 610 (1972).

17. E.g., Credit Suisse Secs. (USA) LLC v. Billing, 551 U.S. 264, 264 (2007) (holding that "securities law implicitly precludes the application of the antitrust laws to the conduct alleged in this case"); Weyerhaeuser Co. v. Ross-Simmons Hardwood Lumber Co., 549 U.S. 312, 318, 326 (2007) (applying a heightened standard to a predatory-bidding claim and holding that the standard was not met).

18. E.g., Atl. Richfield Co. v. USA Petroleum Co., 495 U.S. 328, 340, 346 (1990) (citation omitted) (finding that the plaintiff had suffered "no 'antitrust injury"')); Cargill, Inc. v. Monfort of Colo., Inc., 479 U.S. 104, 117 (1986) (finding that the plaintiff did not sufficiently allege "a threat of antitrust injury" caused by predatory pricing).

19. See Michael D. Shear et al., Obama Chooses Merrick Garland for Supreme Court, N.Y. TiMES (Mar. 16, 2016), http://www.nytimes.com/2016/03/17/us/politics/obamasupreme-court-nominee.html?_r=0 [https://perma.cc/5BCU-587Y] (citing Charles Chamberlain as stating that Garland was a nominee "seemingly designed to appease intransigent Republicans").

20. Roert Barnes \& Ashley Parker, Neil M. Gorsuch Sworn in as $113^{\text {th }}$ Supreme Court Justice, WASH. POST (Apr. 10, 2017), https://www.washingtonpost.com/politics/ courts_law/gorsuch-to-be-sworn-in-to-supreme-court-today-in-two- 
likely to cabin antitrust law even further. ${ }^{21}$

Under progressive leadership, one federal agency, the FTC, could resurrect antitrust law as "a comprehensive charter of economic liberty." 22 Modern administrative law and Congressional delegation of policymaking authority grant the FTC expansive power to interpret the antitrust provision of Section 5 of the FTC Act. ${ }^{23}$ In enacting this statute, Congress articulated a grand progressive-populist vision of antitrust. It wanted the FTC to police "unfair methods of competition" that injure consumers, prevent rivals from competing on the merits, and allow large corporations to dominate our political system. ${ }^{24}$ Congress intended the FTC's antitrust authority to encompass more than the prohibitions in the Sherman and Clayton Acts and to nip anticompetitive problems in the embryonic stage before corporations gained undue power over consumers, small suppliers, competitors, and the American political system. ${ }^{25}$

Since the early 1980s, the FTC has championed antitrust law centered on economic efficiency. In 2015, the FTC codified this approach in a Statement of Enforcement Principles laying out its interpretation of Section 5 's prohibition on unfair methods of competition. ${ }^{26}$ The FTC stated that it would use its Section 5 authority to advance "consumer welfare," which is functionally similar to the allocative efficiency goal, and apply the rule of reason framework. ${ }^{27}$ In articulating this narrow interpretation of Section 5, the FTC contradicted Congress's political economic vision in 1914, which sought to prevent not only short-term injuries to consumers, but also exclusionary practices by large businesses and the accumulation of private

ceremonies/2017/04/10/9ac361fe-1ddb-11e7-ad74-3a742a6e93a7_story.html?utm_ term=.719f53c85f19 [https://perma.cc/5UGA-EQRS].

21. Zephyr Teachout, Neil Gorsuch Sides with Big Business, Big Donors and Big Bosses, WASH. Post (Feb. 21, 2017), https://www.washingtonpost.com/posteverything/wp/ 2017/02/21/neil-gorsuch-always-sides-with-big-business-big-donors-and-big-

bosses/?utm_term=.959433de0043 [https://perma.cc/B5VV-4GDT]; see, e.g., Novell, Inc. v. Microsoft Corp., 731 F.3d 1064, 1075 (10th Cir. 2013) (holding that a monopolist's refusal to deal is actionable under the antitrust laws only if the monopolist sacrificed profits in the process).

22. N. Pac. Ry Co. v. United States, 356 U.S. 1, 4 (1958).

23. See Fed. Trade Comm'n, Statement of Enforcement Principles Regarding "Unfair Methods of Competition" Under Section 5 of the Federal Trade Commission Act, 80 Fed. Reg. 57,056, 57,056 (Sep. 21, 2015) [hereinafter "Section 5 Statement"] (stating that Congress "left the development of Section 5 to the Federal Trade Commission as an expert administrative body").

24. Id.

25. Id.

26. Id. Section 5 also prohibits "unfair or deceptive acts or practices." 15 U.S.C. $\S$ 45(a) (2006). This Article will focus exclusively on the FTC's "unfair methods of competition" authority.

27. Section 5 Statement, supra note 23. 
political power. And in making the rule of reason the centerpiece of its analytical framework, the FTC adopted a convoluted test that cannot advance the Congressional vision underlying Section 5.

Despite being a champion of the efficiency paradigm since 1981, the FTC under progressive leadership in the future could still change course and be true to the Congressional intent from when the agency was created more than a century ago. In setting out an interpretation of Section 5, whether through enforcement actions or rulemakings, the FTC should anchor Section 5 in the expansive political economic vision of Congress. By enacting the FTC Act, Congress sought to prevent-rather than remedy after the fact-three principal harms from concentrated economic power: wealth transfers from consumers and producers to monopolies, oligopolies, and cartels; private blockades against entry and competition in markets; and the accumulation of economic and political power in corporate hands. To advance Congress's antitrust vision, the FTC should adopt presumptions of illegality for a variety of competitively suspicious conduct, such as mergers in concentrated industries, exclusionary practices by firms with market dominance or near-dominance, and restraints on retail competition; and challenge monopolies and oligopolies that inflict significant harm on the public. When seeking to preserve or restore competitive market structures, the FTC should pursue simple structural remedies over complicated behavioral fixes.

This Article proceeds as follows: Part I examines modern administrative law and Congressional intent to show that the FTC has broad power to interpret Section 5. Part II describes the expansive political economic vision-one focused on preventing the rise of concentrated private power-that Congress had when it enacted the FTC Act in 1914. Part III turns to recent FTC policymaking on Section 5. It explains how the Commission, by endorsing the consumer welfare goal and rule of reason framework in its 2015 Statement of Enforcement Principles, failed to honor Congressional intent. Part IV lays out an interpretation of Section 5 that is rooted in Congressional intent and that would advance the three primary goals expressed in the legislative history of the FTC Act. Part V responds to likely objections to the proposed interpretation of Section 5.

\section{THE FTC HAS THE AUthority to DEFINE THE MEANING OF SECTION 5}

The FTC has broad power to define the meaning of Section 5. Modern administrative law gives executive and independent agencies considerable freedom to define the meaning of statutes phrased in general terms. A body of law, originating with the Supreme Court's landmark 
1984 decision Chevron U.S.A., Inc. v. Natural Resources Defense Council, Inc. ${ }^{28}$ has granted elastic quasi-legislative power to the administrative state. The Court held in Chevron that agencies have power to interpret ambiguously worded statutes so long as the interpretation is reasonable. ${ }^{29}$ Section 5 of the FTC Act, with its language on "unfair methods of competition," is the type of generally worded statute that an agency is empowered to interpret. ${ }^{30}$

In addition to interpretive authority under Chevron, when Congress enacted the FTC Act in 1914, it expressly granted the Commission the power to define the meaning of "unfair methods of competition." Congress was reacting to the Supreme Court decision in Standard Oil Co. v. United States in which the Court held that it had the ultimate power to interpret the Sherman Act. ${ }^{31}$ In delegating the power to define "unfair methods of competition" to the FTC, Congress sought to reassert control over the development of antitrust policy and prevent the courts from subverting legislative desires.

\section{A. Modern Administrative Law Gives the FTC Broad Discretion to Interpret Section 5}

Modern administrative law has transferred significant lawmaking power from the courts to the numerous executive and independent agencies in the federal government. Questions of statutory interpretation that were once the jealous prerogative of the courts are now often resolved by, for example, the Department of Labor, the Environmental Protection Agency, or the Federal Communications Commission. While agency statutory interpretations are still subject to judicial review, interpretations of statutes phrased in general terms are examined under a deferential legal standard.

The Supreme Court's Chevron decision revolutionized administrative law and policymaking in the United States. In reviewing a challenge to an interpretation of the Clean Air Act by the Environmental Protection Agency, the Court established a deferential standard of review for agency interpretations of statutes. The Court held that an agency's interpretation of a statute would be accorded deference if the statute is ambiguously

28. 467 U.S. 837 (1984).

29. Id. at $842-45$.

30. Justin (Gus) Hurwitz, Chevron and the Limits of Administrative Antitrust, $76 \mathrm{U}$. PITT. L. REV. 209, 248 (2014); Royce Zeisler, Chevron Deference and the FTC: How and Why the FTC Should Use Chevron to Improve Antitrust Enforcement, 2014 ColuM. Bus. L. REV. 266, 291-92 (2014).

31. 221 U.S. 1, 69-70 (1911). 
worded and the agency's interpretation is reasonable..$^{32}$ In practice, Chevron deference has meant that an agency's interpretation is permissible unless the statute's language expressly forecloses this particular interpretation. ${ }^{33}$ Chevron deference represents a transfer of power from the courts to the executive branch. Statutes that were traditionally interpreted by the federal courts are now often given meaning by federal agencies. ${ }^{34}$

The Court in Chevron justified this transfer of lawmaking and policymaking functions to agencies on multiple grounds. First, open-ended statutory language presumably reflects a desire on the part of Congress for agencies to interpret the statute. ${ }^{35}$ Second, the Court stated that agencies are better equipped than the courts, both in terms of expertise and resources, to decide the technical questions often implicated in statutory interpretation. ${ }^{36}$ Third, the Court stated that agency heads, while they are not selected by popular vote, do answer to the democratically elected president. ${ }^{37}$ As such, agencies face more public accountability than federal judges with life tenure.

An agency's interpretation of a statute does not have to be articulated through notice-and-comment rulemaking to receive Chevron deference. Agencies have broad discretion over the policy instrument that they use to articulate interpretations of a statute. ${ }^{38}$ While notice-and-comment rulemakings are one of the most common means of propounding an interpretation of a statute, interpretations made through formal adjudications are also typically entitled to Chevron deference. ${ }^{39}$ Whether Chevron deference applies to interpretations made through other means, such as policy statements, is decided on a case-by-case basis. ${ }^{40}$

32. Chevron, 467 U.S. at 843-45

33. Matthew C. Stephenson \& Adrian Vermeule, Chevron Has Only One Step, 95 VA. L. REV. 597, 601 (2009).

34. See Thomas J. Miles \& Cass R. Sunstein, Do Judges Make Regulatory Policy? An Empirical Investigation of Chevron, 73 U. CHI. L. REV. 823, 833 (2006) (exploring the connection between the rate at which judges validate agency interpretations and their political ideologies).

35. Chevron, 467 U.S. at 843-44.

36. Id. at 865 .

37. Id.

38. See NLRB v. Bell Aerospace Co., 416 U.S. 267, 294 (1974) ("[T]he Board is not precluded from announcing new principles in an adjudicative proceeding and . . the choice between rulemaking and adjudication lies in the first instance within the Board's discretion."); SEC v. Chenery Corp., 332 U.S. 194, 203 (1947) ("[T]he choice made between proceeding by general rule or by individual, ad hoc litigation is one that lies primarily in the informed discretion of the administrative agency.").

39. United States v. Mead Corp., 533 U.S. 218, 230-31 (2001).

40. Barnhart v. Walton, 535 U.S. 212, 222 (2002); Cass R. Sunstein, Chevron Step Zero, 92 VA.L. REV. 187, 218 (2006). 
Agencies also have the power to revise and reverse earlier statutory interpretations. The Supreme Court decision in National Cable \& Telecommunications Ass' $n$ v. Brand $X$ Internet Services ${ }^{41}$ upheld a significant change in the Federal Communications Commission's interpretation of a statutory provision. Provided they offer a reasoned explanation for the changed interpretation, agencies' revised interpretations of a statute are entitled to Chevron deference. ${ }^{42}$ Agencies are thereby not bound by prior interpretations. They have the power to interpret and reinterpret ambiguously phrased statutes over time. Recently, the Supreme Court granted agencies procedural flexibility on revisiting interpretive rules, policy statements, and other regulatory interpretations that were not made through notice-and-comment rulemaking. In Perez v. Mortgage Bankers Ass' $n$, the Court held that agencies can subsequently revise these less formal interpretations without going through the notice-and-comment process. $^{43}$

The FTC's interpretation of Section 5's prohibition on unfair methods of competition is almost certain to receive Chevron deference. The words "unfair methods of competition" are not self-defining and susceptible to multiple interpretations. These words are open-ended in content and, on their face, allow for a broad range of permissible interpretations. One scholar has succinctly captured how nebulous Section 5 is: "Nearly every word of the statute is rife with ambiguity: What is unfair? Unfair to whom? ... What is a method? ... What is competition?" ${ }^{44}$ In light of its wording, Section 5 appears to be the paradigmatic example of a statute whose interpretation is entitled to Chevron deference.

\section{B. Congress in 1914 Expressly Delegated Power to the FTC to Interpret Section 5}

Congress, in creating the FTC, expressly sought to empower the agency to define the meaning of "unfair methods of competition." The Congress that enacted the FTC Act was reacting to the Supreme Court's landmark ruling in Standard Oil Co. v. United States. ${ }^{45}$ In this decision, the Court had established the rule of reason as the framework for analyzing most trade restraints and held that it had the power to articulate the meaning of the Sherman Act. ${ }^{46}$ Congress passed the FTC Act to reestablish

41. 545 U.S. 967, 1000-01 (2005).

42. Id. at 981-82; FCC v. Fox Television Stations, Inc., 556 U.S. 502, 515-16 (2009).

43. 135 S. Ct. 1199,1206 (2015).

44. Hurwitz, supra note 30 , at 248-49.

45. 221 U.S. 1, 69-70 (1911).

46. Id. 
control over the development of competition policy and accordingly delegated the authority to define unfair methods of competition to the FTC. In light of this history, the FTC could arguably claim that its interpretation of Section 5 is entitled to deference, even in the absence of Chevron. ${ }^{47}$

The Supreme Court's decision in Standard Oil generated much public and congressional outrage. Although the Court had found the oil refining giant liable for monopolization and ordered the dissolution of the company, the Court also implicitly claimed the prerogative of interpreting the Sherman Act under the rule of reason framework. ${ }^{48}$ The decision was seen as a power grab by the Court. ${ }^{49}$ The courts were anti-populist and pro-big business and routinely struck down federal and state public interest regulation that protected ordinary Americans. ${ }^{50}$ Given this elitist orientation of the federal courts, many feared that the rule of reason meant the evisceration of the Sherman Act. ${ }^{51}$ The holding in Standard Oil was a major step in this direction as it established, in the common law of the Sherman Act, two classes of monopolies: bad monopolies and good monopolies. ${ }^{52}$

In the wake of the 1912 election that involved passionate debates and

47. For an example of the Court granting deference to an agency interpretation of a statute on account of express Congressional delegation of authority, see Schweiker v. Gray Panthers, 453 U.S. 34, 44 (1981) (citation omitted) ("In view of this explicit delegation of substantive authority, the Secretary's definition [of the contested term] ... is entitled to 'legislative effect' because, 'in a situation of this kind, Congress entrusts to the Secretary, rather than to the courts, the primary responsibility for interpreting the statutory term."'). But see, e.g., E.I. du Pont de Nemours \& Co. v. FTC, 729 F.2d 128, 137 (2d. Cir 1984) (“As the Commission moves away from attacking conduct that is either a violation of the antitrust laws of collusive, coercive, predatory, restrictive or deceitful, and seeks to break new ground by enjoining otherwise legitimate practices, the closer must be our scrutiny upon judicial review.").

48. Dow Votaw, Antitrust in 1914: The Climate of Opinion, 24 ABA SEC. OF ANTitrust L. 14, 20-21 (1964).

49. Id. at 21; Neil W. Averitt, The Meaning of "Unfair Methods of Competition" in Section 5 of the Federal Trade Commission Act, 21 B.C. L. REv. 227, 231 (1980). Justice Harlan in his dissent accused his colleagues in the majority of seizing legislative powers for the Supreme Court. Standard Oil, 221 U.S. at 83 (Harlan, J., dissenting).

50. E.g., Adair v. United States, 208 U.S. 161 (1908) (striking down a ban on yellowdog contracts), overruled in part by Phelps Dodge Corp. v. NLRB, 313 U.S. 177 (1941); Lochner v. New York, 198 U.S. 45 (1905) (striking down a law that limited the number of hours that bakery employees could work), overruled in part by Ferguson v. Skrupa, 372 U.S. 726 (1963); K. Sabeel Rahman, Domination, Democracy, and Constitutional Political Economy in the New Gilded Age: Towards a Fourth Wave of Legal Realism, 94 TEX. L. REV. 1329, 1329-30 (2016).

51. Marc Winerman, The Origins of the FTC: Concentration, Cooperation, Control, and Competition, 71 ANTITRUST L.J. 1, 13-14 (2003).

52. Eleanor M. Fox \& Lawrence A. Sullivan, The Good and Bad Trust Dichotomy: A Short History of a Legal Idea, 35 ANTITRUST BULLETIN 57, 80 (1990). 
competing visions of antitrust,${ }^{53}$ Congress sought to reclaim authority over competition policy. Among those who favored additional antitrust legislation, a significant policy disagreement existed. Some supported a law that would prohibit a list of problematic practices, while others endorsed a general prohibition on anticompetitive behavior, akin to what Congress had done earlier with the Sherman Act. ${ }^{54}$ A statute that prohibited enumerated practices would provide greater legal guidance and certainty for businesses. ${ }^{55}$ It, however, would almost certainly be underinclusive $^{56}$ and susceptible to evasion over time, as profit-oriented businesses found new ways to engage in anticompetitive behavior. ${ }^{57}$ Congress ultimately pursued both options: it passed the Clayton Act that prohibited particular practices and the FTC Act that outlawed unfair methods of competition in general. ${ }^{58}$

Congress created the FTC to maintain control over the meaning of unfair methods of competition and granted the Commission interpretive authority. Without the Commission, the members of Congress and Senators involved in drafting the FTC Act feared that the courts would apply a restrictive "judicial gloss" on unfair methods of competition." Congress created the Commission "to exercise a legislative function to the extent of determining what constitutes an unfair method of competition.," The FTC was created to act, in effect, as an arm of Congress that would use its expertise and investigatory powers to advance the legislative will. Laying out a vision of political accountability, Senator Newlands wanted a new commission to be "the servant of Congress." 61 Senator Cummins stressed the political accountability of a commission and touted the superiority of "a commission at all times under the power of Congress, at all times under the eye of the people" over "the comparative seclusion of the courts." ${ }^{.2}$

To guard further against judicial encroachment in the interpretation of

53. See generally Daniel A. Crane, All I Really Need to Know About Antitrust I Learned in 1912, 100 IowA L. REV. 2025 (2015) (noting that debates about the benefits of a competitive economy were pervasive in the rhetoric of the 1912 presidential candidates).

54. Winerman, supra note 51, at 3-5.

55. See, e.g., Winerman, supra note 51, at 52, 74 (noting that President Wilson in his 1912 campaign had promoted a statute with specific prohibitions and that proponents of the FTC Act believed in the value of a generally-worded prohibition).

56. Winerman, supra note 51, at 67.

57. Averitt, supra note 49, at 234.

58. 15 U.S.C. $\$ \S 2,3,7$ (2015); 15 U.S.C. $\S 45$ (2015).

59. Averitt, supra note 49, at 230, 236; Winerman, supra note 51, at 76.

60. A. Everette MacIntyre \& Joachim J. Volhard, The Federal Trade Commission and Incipient Unfairness, 41 GEO. WASH. L. REV. 407, 416 (1973).

61. 47 CONG. REC. 1225 (1911).

62. 51 CONG. REC. 13047 (1914). 
Section 5, Congress took another important step. The drafters of the FTC Act adopted the term of art "unfair methods of competition." ${ }^{63}$ Initial drafts used the established term "unfair competition." ${ }^{64}$ This term was (and still is) associated with a large body of common law concerning businesses passing off their goods as those of a rival, ${ }^{65}$ rather than anticompetitive practices. Using the term "unfair competition" and indirectly invoking the related precedent in the statute raised the specter of the courts once again thwarting congressional will. Members of Congress feared that courts would use this language to assert authority to interpret Section 5 and, in particular, apply the precedent on "unfair competition" to narrow what Congress intended to be an expansive statute. ${ }^{66}$

The Supreme Court has recognized the policymaking power that Congress granted to the FTC. In FTC v. Sperry \& Hutchinson Co., the Court observed that Congress wanted to preserve interpretive flexibility when it prohibited unfair methods of competition. ${ }^{67}$ The Court stated that Congress, by design, declined to anchor "the concept of unfairness to a common-law or statutory standard or by enumerating the particular practices to which it was intended to apply." ${ }^{\circ 8}$ As such, unfair methods of competition are not limited to acts that may violate the other antitrust statutes. $^{69}$ In affirming the Commission's broad policymaking power, the Court held that the FTC "does not arrogate excessive power to itself if, in measuring a practice against the elusive, but congressionally mandated standard of fairness, it, like a court of equity, considers public values beyond simply those enshrined in the letter or encompassed in the spirit of the antitrust laws." ${ }^{70}$ A subsequent Supreme Court decision affirmed the Commission's power to define unfair methods of competition. ${ }^{71}$

\section{IN ENACTING THE FTC ACT, CONGRESS HAD AN EXPANSIVE VISION FOR SECTION 5}

The Congress that enacted the FTC Act and created the Commission had an ambitious progressive-populist vision for the new agency. It

63. Averitt, supra note 49 , at 235.

64. Averitt, supra note 49, at 235.

65. Averitt, supra note 49, at 235.

66. Averitt, supra note 49, at 235. Supporters of the FTC Act had much less faith in the courts than those who believed the Sherman Act's rule of reason was sufficient to control monopoly power. Winerman, supra note 51, at 76 .

67. 405 U.S. 233, 239-40 (1972).

68. Id.

69. Id. at 244 .

70. Id. (emphasis added).

71. FTC v. Ind. Fed'n of Dentists, 476 U.S. 447, 454-55 (1986). 
established an agency with enforcement, research, and policymaking powers. In granting the agency the power to prohibit the open-ended "unfair methods of competition," Congress expressed expansive political economic aims that should guide the Commission's exercise of its powers. Congress aimed to protect consumers and producers from wealth-extracting firms with market power, preserve open markets for all comers, and prevent the concentration of private power. Congress had expressed similar objectives in enacting the Sherman and Clayton Acts.

Section 5 was meant to be narrower in some respects than the other two principal antitrust statutes-and broader in others. Unlike the substantive provisions of the Sherman and Clayton Acts, Section 5 lacks a private right of action or a treble damages remedy. ${ }^{72}$ Congress, however, intended it to reach a wider array of conduct than the other two antitrust statutes. Importantly, Congress wanted Section 5 to be an incipiency statute, which nips anticompetitive practices in the bud and prevents monopolies and oligopolies from developing in the first place.

\section{A. Section 5 of the FTC Act Has a Multifaceted Political Economic Purpose}

Congress, in creating the FTC, had an ambitious vision for its Section 5 powers. While the term "unfair methods of competition" is vague and susceptible to multiple interpretations, the legislative debates culminating in the passage of the FTC Act reveal three central purposes. The members of Congress involved in drafting and passing the FTC Act wanted to protect consumers from wealth transfers, maintain markets open to all comers, and prevent the concentration of private economic and political power. These goals are remarkably similar to those expressed in the debates leading up to the enactment of the Sherman and Clayton Acts. ${ }^{73}$ Congress enacted the antitrust laws in response to growing public fears about and hostility toward the large-scale corporate entities that emerged in

72. Amy Marshak, The Federal Trade Commission on the Frontier: Suggestions for the Use of Section 5, 86 N.Y.U.L.REV. 1121, 1128 (2011).

73. See generally Robert H. Lande, Wealth Transfers as the Original and Primary Concern of Antitrust: The Efficiency Interpretation Challenged, 34 HASTINGS L.J. 65 (1982) (noting that the floor debates over federal antitrust legislation suggest that Congress "condemned monopolies"); James May, Antitrust in the Formative Era: Political and Economic Theory in Constitutional and Antitrust Analysis, 1880-1918, 50 ОH. ST. L.J. 257 (1989) (discussing legislators' conflicting views on concentrated capitalism in the early twentieth century). Congress reaffirmed this broad vision in subsequent antitrust statutes. Peter W. Rodino, Jr., The Future of Antitrust: Ideology Vs. Legislative Intent, 35 ANTITRUST BuLl. 575, 583-88 (1990). 
the decades following the Civil War. ${ }^{74}$ Contrary to Robert Bork and other conservative thinkers, the legislative histories of the FTC Act do not show a concern with promoting economic efficiency as defined by neoclassical economics, or even an awareness of the concept. ${ }^{75}$

The legislative debates reveal a widely shared anger toward large businesses that used their power to extract wealth from consumers and producers and a desire for the FTC to prevent this type of redistribution. Several members of Congress and Senators expressed outrage at how corporations could use their power in the market to raise prices and capture the wealth of the consuming public. As Robert Lande has shown, the prevention of redistribution through the exercise of market power was an important objective. ${ }^{76}$ Congress sought to prevent large corporations from using their power to deprive consumers of the benefits of technical progress and producers of the fruits of their labor. A sample of quotes from the legislative debate underscores the importance of this goal. The principal sponsor of the FTC Act in the Senate condemned "unreasonable and extortionate prices." 77 A colleague, Senator Lane, stated that Americans are "being compelled to pay arbitrarily fixed and unjustly high prices for what they consume [and that] they are being robbed."78 Representative Morgan expressed hope that the FTC would "minimize the power of the large industrial corporation to concentrate wealth ... and secure the people from unjust tribute levied by monopolistic corporations." 79 A House report noted that powerful purchasers (monopsonies and oligopsonies in modern economic terms) could similarly use their power to depress prices paid to employees and other small producers. ${ }^{80}$

74. See David Millon, The Sherman Act and the Balance of Power, 61 S. CAL. L. REv. 1219,1226 (1988) ("The advent of big business on this massive scale was a traumatic event. '[T]he old gentry, the merchants of long standing, the small manufacturers, the established professional men, the civic leaders of an earlier era' saw themselves deprived of economic power, opportunity, personal independence, and social status. This urban middle class, the backbone of the progressive reform movement, was profoundly antagonistic to big business, and no one complained more bitterly than the owners of small businesses. Agrarian populism also identified big business, particularly the great railroad combinations, with the farmer's increasingly tenuous control over his livelihood. Labor sought strength in collective organization to protect itself from the power of massed capit Thus, a broad spectrum of American society complained bitterly about the evil powers of the trusts.").

75. Barak Orbach, How Antitrust Lost Its Goal, 81 FORDHAM L. REV. 2253, 2275 (2013) (quoting Robert H. Bork, The Antitrust Paradox: A Policy AT WAR With Itself 427 (rev. ed. 1993).

76. Lande, supra note 73 , at 112-14.

77. S. REP. NO. 63-597, at § 7 (1914).

78. 51 CONG. ReC. 13223 (1914).

79. Id. at 8854 .

80. H.R. REP. No. 63-533, pt. 1, at 14 (1914). 
The Congressional debates also indicate a commitment to preserving the openness of markets to all parties. Several members of Congress and Senators expressed fear that large corporations would use their power to exclude smaller rivals from the market. Senator Reed stated this commitment to open markets eloquently: "We are trying to keep the highways of opportunity unobstructed. We are trying to keep it so that the feet of the men of today may travel along an open path, so that all may have a fair chance to gain a livelihood and to embark in business." ${ }^{81}$

In expressing this desire to maintain open markets, Senator Reed was far from alone among his peers. Senator Burton sought to ensure "a free field for all" in business and warned against irresistible corporate power under which "equality of opportunity shall be destroyed or the deserving competitor driven out of business." ${ }^{2}$ Senator Lane worried that, without the FTC, the typical small enterprise would be "driven out of business by his larger or more crafty rival." 83

The fears about concentrated economic and political power and indeed private autocracy were another important theme in the legislative debates. The threat to democratic institutions from concentrated private power had been a recurring motivation in enacting the other antitrust statutes. ${ }^{84}$ Senator Kenyon stated: "[I]f this Government is powerless to destroy monopoly, then we have got to concede that monopoly is powerful enough to destroy this Government." ${ }^{85}$ A House Minority Report lamented how "[f]ifty men in the United States control, through interlocking directorates, forty percent of the wealth of the country." $" 86$ Congressman Stevens observed that: "vast wealth has been accumulated, especially in the hands of a few, irresponsible except to their own consciences and sense of justice and patriotism" and noted that "the great mass of our people have a very just apprehension that this wealth, and [the] power growing out of it... may be a potential source of injury and oppression." 87 He endorsed the creation of an FTC because it would guard the public against this concentration of private power. ${ }^{88}$ Senator Cummins even raised the possibility of corporate dictatorship. He warned his colleagues against valuing cheap goods and services too highly "if it involves the surrender of the individual, the subjugation of a great mass of people to a single master

\footnotetext{
81. 51 CONG. REC. 13231 (1914).

82. Id. at 14792 .

83. Id. at 13223 .

84. May, supra note 73, at 296-97.

85. 51 Cong. ReC. 13158 (1914).

86. H.R. REP. No. 63-533, pt. 3, at 5 (1914).

87. 51 CONG. REC. 8850 (1914).

88. Id. at 14938 .
} 
mind." 89

\section{B. Section 5 Is Intended to Be Broader than the Other Antitrust Laws}

While the legislative themes underlying the FTC Act bear a close resemblance to those underlying its sister antitrust laws, the Sherman and Clayton Acts,${ }^{90}$ Congress aimed to go further in some important ways when it established the FTC. Neil Averitt's landmark article on Section 5 laid out several possible interpretations, which ranged from a statute that is coterminous with the other antitrust laws to one that allows the FTC to police virtually all types of business conduct. ${ }^{91}$ Among these interpretations, an uncontroversial one is that Section 5 is intended, like the Clayton Act, to be an incipient measure that prevents competitive problems before they have come to fruition. ${ }^{92}$ In other words, Section 5 has a strong prophylactic orientation.

This incipiency theme is evident in the legislative debates. Indeed, Congress and many members of the public were frustrated with the Sherman Act's inability to tackle nascent threats to competition. ${ }^{93}$ Afterthe-fact legal action was seen as unable to address monopolies. ${ }^{94}$ Once a corporation became a monopoly, it became difficult to restructure the market and restore competition. To maintain competitive markets, early and decisive legal action against anticompetitive conduct was considered essential. President Wilson also championed a preventative approach to antitrust policy. ${ }^{95}$

Averitt has noted that " $[\mathrm{t}]$ he legislative history of the Federal Trade Commission Act is replete with references which reiterate that the function of the Commission would be to arrest trade restraints in their incipiency." 96

89. Id. at 12742 .

90. See generally Lande, supra note 73, at 82-142 (discussing the similar congressional goals of economic efficiency and protecting consumers from unfair wealth transfers behind the various antitrust laws); May, supra note 73, at 288-300 (noting the "widespread congressional commitment to the long-established ideals of economic opportunity, security of property, freedom of exchange, and political liberty").

91. See Averitt, supra note 49, at 238-96.

92. Id. at 242-51.

93. See Averitt, supra note 49, at 243 (noting the importance of stopping antitrust violations in their incipiency); see also Winerman, supra note 51, at 74 (discussing the congressional support for stopping anticompetitive acts at the start).

94. See MacIntyre \& Volhard, supra note 60 , at 414 (emphasizing the difficulties in addressing antitrust issues once a trend of concentration had already become evident).

95. Id. at 414 n.39 (noting President Wilson's belief that stopping anticompetitive acts in their incipiency would help small businessmen have a place in the market). 15).

96. Averitt, supra note 49, at 243 (citing MacIntyre \& Volhard, supra note 60, at 414- 
The Conference Committee report stressed this theme of prevention. ${ }^{97}$ Senator Reed stated that the goal was "to strike those [anticompetitive] acts in their incipiency instead of after they have been actually worked out into a complete system of monopoly or restraint of trade." Similarly, Senator Newlands sought to check monopoly "in the embryo." 99 Senator Cummins aspired "to seize the offender before his ravages" 100 had violated existing antitrust rules, and Representative Covington sounded a similar theme and stated that " $[w]$ hat we wish to do and ought to do above everything else is to prevent the growth of monopoly at the beginning." 101

The courts have affirmed the incipiency standard in Section 5. While the judiciary has not addressed incipiency-or even Section 5 more generally-in decades, the most recent decisions are unequivocal that Section 5 is intended to prevent anticompetitive behavior in its infancy. The Supreme Court has stated that Section 5 is intended "to stop in their incipiency acts and practices which, when full blown, would violate [the antitrust] Acts" 102 and that "Congress enacted $\S 5$ of the Federal Trade Commission Act to combat in their incipiency trade practices that exhibit a strong potential for stifling competition." "103 In Fashion Originators Guild v. FTC, the Supreme Court similarly acknowledged this legislative purpose behind the FTC Act, stating that the sponsors hoped "that its effect might be prophylactic and that through it attempts to bring about complete monopolization of an industry might be stopped in their incipiency." 104

The courts have held that the Section 5 incipiency standard applies in cases that implicate the Clayton Act, which has its own incipiency standard. ${ }^{105}$ Among other things, the Clayton Act covers mergers and exclusive dealing in the sale of goods. ${ }^{106}$ In FTC v. Brown Shoe Co., the Supreme Court rejected the defendant's contention that the Commission must show a substantial likelihood of harm to competition. ${ }^{107}$ Instead, the Court held that the FTC "has power under $\S 5$ to arrest trade restraints in

97. See H.R. REP. No. 63-1142, at 19 (1914) (stressing the importance of stopping monopolies at the outset).

98. 51 CONG. REC. 13118 (1914).

99. Id. at 12030 .

100. Id. at 11455 .

101. Id. at 14941 .

102. FTC v. Motion Picture Advert. Serv. Co., 344 U.S. 392, 394-95 (1953).

103. FTC v. Texaco Inc., 393 U.S. 223, 225 (1968).

104. 312 U.S. 457, 466 (1941).

105. Averitt, supra note 49, at 246-47.

106. 15 U.S.C. $\S \S 14,18$ (2015).

107. See FTC v. Brown Shoe Co., 384 U.S. 316, 322 (1966) (rejecting the argument that outright proof of a Section 3 Clayton violation is necessary for a Section 5 FTC Act violation). 
their incipiency without proof that they amount to an outright violation of $\S$ 3 of the Clayton Act or other provisions of the antitrust laws." 108

\section{THE FTC's 2015 AFFIRMATION OF A LIMITED ANTITRUST THAT CONTRAVENES CONGRESS' GOALS}

The FTC has interpreted Section 5 narrowly in recent decades. The Commission's expansive interpretation of Section 5 in the mid-twentieth century is a distant memory in 2017. The FTC suffered three appellate defeats in Section 5 matters in the early 1980 s, ${ }^{109}$ which appear to have instilled a multi-decade timidity. For the past thirty years, the Commission has invoked Section 5 infrequently in litigation and settlements and has been rather modest when it has. When the Commission has brought standalone Section 5 actions in the intervening years, these cases have represented only marginal extensions of existing Sherman Act precedent. ${ }^{110}$ None of these actions have questioned the framework of contemporary antitrust or sought to broaden its normative lens. While the FTC's Section 5 antitrust authority has not been strengthened since the three appellate losses in the 1980s, these cases preceded the Chevron revolution in administrative law. ${ }^{111}$

Just as monopoly, economic power, and antitrust reemerged as a topic of public debate, the FTC, in its 2015 Statement of Enforcement Principles, voluntarily limited the scope of its power and affirmed its commitment to the antitrust status quo. ${ }^{12}$ The Section 5 Statement endorses a limited policy program that fails to reflect Congress' vision in establishing the Commission. The FTC stated that consumer welfare would be the guiding principle in its Section 5 actions and that the rule of reason would be the default analytical framework in such cases. ${ }^{113}$ In establishing consumer

108. Id.

109. See E.I. Du Pont De Nemours \& Co. v. FTC, 729 F.2d 128, 142 (2d Cir. 1984) (vacating the FTC's order finding manufacturers of gasoline additives had conducted unfair competition methods); Official Airline Guides, Inc. v. FTC, 630 F.2d 920, 928 (2d Cir. 1980) (reversing an order from the FTC forcing publisher of airline schedules to publish certain connecting flights); Boise Cascade Corp. v. FTC, 637 F.2d 573, 582 (9th Cir. 1980) (denying enforcement of an FTC order holding that manufacturers of plywood violated the FTC Act by using a delivered pricing system).

110. See, e.g., Complaint at *9-12, In re Negotiated Data Sols. LLC, F.T.C. No. 510094, 2008 F.T.C. LEXIS 119 (Sept. 22, 2008) (alleging patent holder reneged on licensing commitment following commercialization of technical standard that included patent); In re Valassis Commc'ns, Inc., 141 F.T.C. 247, 249-52 (2006) (alleging invitation to collude).

111. Hurwitz, supra note 30, at 254.

112. See Section 5 Statement, 80 Fed. Reg. at 57,056 (stating that Section 5 would track judicial interpretations of the Sherman and Clayton Acts where applicable).

113. Id. 
welfare as the sole objective of Section 5 enforcement, the FTC elevated the conservative ideology and false historical analysis of Robert Bork and other Chicago School academics over Congress's intent in creating the Commission. Congress wanted to advance a broad political economic vision and prevent monopolies and oligopolies from emerging, rather than wait to attack them after they had become entrenched. In addition to defining the goal of Section 5 too narrowly, the FTC endorsed the rule of reason, a deficient analytical framework. In practice, the rule of reason confers de facto legality on a range of problematic business conduct.

\section{A. The FTC Doubled Down on the Ahistorical Efficiency Paradigm}

In its Section 5 Statement, the FTC affirmed its commitment to the neoclassical interpretation of antitrust law. The Commission stated that its Section 5 actions would be "guided by the goal of promoting consumer welfare."114 By using this language, the FTC did not present as much clarity as it might have thought it did. In the antitrust world, "consumer welfare" is not a settled term and has been the source of a running debate between those who believe consumer welfare should cover flesh-and-blood consumers and those who believe it should account for the welfare of consumers and producers. Regardless of the interpretation the FTC intended to adopt, it failed to honor Congress's intentions in enacting Section 5. When it passed the FTC Act, Congress viewed the protection of consumers as only one of several antitrust goals that the new Commission should advance. ${ }^{115}$

The definition of consumer welfare has been a contentious topic in modern antitrust. One camp, generally associated with conservative thinkers ("conservative consumer welfare"), claims that consumer welfare means allocative economic efficiency ${ }^{116}$ and should capture both profitsthe welfare of producers - and consumer wellbeing. ${ }^{117}$ A group of

114. Id.

115. See supra part II.A.

116. Allocative efficiency exists when goods and services are produced up to a point at which the marginal benefit to the purchaser equals the marginal cost of production. If antitrust law promotes allocative efficiency, it seeks to police conduct that prevents the production of goods and services from reaching the socially optimal level. This so-called deadweight loss means that the marginal benefit from additional output exceeds the marginal cost. Critically, this marginal benefit is tied to a consumer's willingness and ability to pay. Under the allocative efficiency framework, a wealthy person's desire for a luxury vacation home is accorded more significance than a poor person's need for lifesaving healthcare. See Barak Orbach, Was the Crisis in Antitrust a Trojan Horse?, 79 ANTITRusT L.J. 881, 893-94 (2013).

117. See, e.g., Dennis W. Carlton, Does Antitrust Need To Be Modernized?, 21 J. Econ. 
progressive antitrust scholars ("progressive consumer welfare") argues that consumer welfare, as Congress meant it, means protecting consumers from the wealth transfers associated with the higher prices from monopolies, oligopolies, and cartels. ${ }^{118}$ Notwithstanding their differences, both interpretations are rooted in the logic of neoclassical economics and focus on the short-run material effects of market power. ${ }^{119}$

Progressive consumer welfare has much stronger historical support than the conservative conception. The progressive understanding of consumer welfare has deep grounding in the legislative histories of the FTC Act as well as the Sherman and Clayton Acts. ${ }^{120}$ Although they did not conceive of antitrust in the technical terms of economics, the members of Congress and Senators involved in drafting and debating the FTC Act aimed to prevent powerful corporations from exacting overcharges on and thereby transferring wealth from the consuming public. ${ }^{121}$ In contrast, they showed no intent to advance the goal of conservative consumer welfare. ${ }^{122}$

While progressive consumer welfare is anchored in the legislative history of the FTC Act, protecting consumers from anticompetitive overcharges is only one of the goals that Congress had in creating the Commission in 1914. Congress did not express a solely consumerist purpose. It conceived of the antitrust laws as political and social statutes, not pure economic measures. ${ }^{123}$ Along with preventing powerful businesses from exacting wealth from consumers, two other themes dominated the debates leading to the passage of the FTC Act. First, the members of Congress who drafted the statute wanted to prevent dominant businesses from using their power to drive out smaller rivals and close markets to competitors. ${ }^{124}$ They believed that monopolists and oligopolists had to be checked through federal legislation because they had the raw

PeRsPeCtIVES 155, 156-59 (2007) (arguing that antitrust laws should maximize total surplus, not just consumer surplus).

118. See, e.g., Steven C. Salop, Question: What Is the Real and Proper Antitrust Welfare Standard? Answer: The True Consumer Welfare Standard, 22 LOY. CONSUMER L. REV. 336, 336-38 (2009) (placing the emphasis on consumer harm rather than an aggregated standard including seller welfare).

119. See John J. Flynn, The Reagan Administration's Antitrust Policy, "Original Intent" and the Legislative History of the Sherman Act, 33 ANTITRUST Bull. 259, 264 (1988) (noting that both conservative and progressive consumer welfare advocates utilize "latterday economic theory" to parse congressional intent in the Sherman Act).

120. See generally Lande, supra note 73 (discussing the desire to prevent unfair wealth transfers as a common goal behind the various antitrust statutes).

121. Lande, supra note 73 , at 112-13.

122. See Flynn, supra note 119, at 299.

123. Peter C. Carstensen, Antitrust Law and the Paradigm of Industrial Organization, 16 U.C. DAVIS L. REV. 487, 487-88 (1983).

124. See supra Section II.a. 
power to control markets and represented an existential threat to small businesses and entrepreneurs. ${ }^{125}$ Second, the authors of the FTC Act sought to forestall concentrations of private power. ${ }^{126}$ They feared that corporate giants threatened to undermine American democracy and transform the institutions of the state into their servants. ${ }^{127}$

In endorsing the language of "consumer welfare," the Section 5 Statement failed to honor Congress's aims in enacting the FTC Act. At best, the FTC fulfilled only one of the goals Congress set out in its founding statute. Even if the Commission embraces progressive consumer welfare, it would still not do justice to what Congress intended. The Commission would disregard the other two principal objectives that Congress envisioned. The Section 5 Statement did not acknowledge the Congressional aims of maintaining open markets and preventing the concentration of private power. It focused exclusively and narrowly on the economic well-being of consumers while ignoring the political and social objectives of the FTC Act. In a speech to announce the publication of the Section 5 Statement, Chairwoman Edith Ramirez stressed the focus on consumer welfare and seemed to disparage the political and social aims of the FTC Act as "public policy concerns unrelated to competition."128 As former FTC Chairman Robert Pitofsky wrote, this disregard for the political goals of antitrust is "bad history, bad policy, and bad law."129

\section{B. The FTC Endorsed a Legal Standard that Grants Powerful Businesses Carte Blanche to Control Markets}

Along with adopting the narrow goal of consumer welfare, the FTC stated that its Section 5 cases would rely on "a framework similar to the rule of reason." 130 The rule of reason requires a deep investigation of the

125. See supra Section II.a.

126. See supra Section II.a.

127. See supra Section II.a.

128. Chairwoman Edith Ramirez, Fed. Trade Comm'n, Address at Competition Law Center at George Washington University Law School 5 (Aug. 13, 2015), https://www.ftc.gov/system/files/documents/public_statements/735411/150813section5spee ch.pdf [https://perma.cc/UAH6-K4E2].

129. Robert Pitofsky, The Political Content of Antitrust, 127 U. PA. L. REV. 1051, 1051 (1979).

130. Statement of Enforcement Principles Regarding "Unfair Methods of Competition" Under Section 5 of the Federal Trade Commission Act, 80 Fed. Reg. 57,056, 57,056 (Sept. 21, 2015). Chairwoman Ramirez stated that the rule of reason in the Section 5 Statement should be understood in "its broad, modern sense." Ramirez, supra note 125, at 7. She added that this means that "the rule of reason does not "necessarily ... call for the fullest market analysis' in all cases." Ramirez, supra note 128, at 7 . While the FTC could analyze a range of conduct under the truncated rule of reason or even presumptions of illegality, it is 
relevant industry and credible evidence of actual or likely anticompetitive outcomes, defined today to mean higher prices or reduced economic output. ${ }^{131}$ For a plaintiff to establish a prima facie case under the rule of reason, it must typically show actual or likely anticompetitive effects from the conduct being challenged. ${ }^{132}$ When a plaintiff demonstrates likely anticompetitive effects, the defendant has the opportunity to rebut this showing through the presentation of efficiencies and other business justifications from the conduct. ${ }^{133}$ The plaintiff can then either rebut the justification (restraint does not promote procompetitive benefits or there are substantially less restrictive alternatives) or show that the anticompetitive effects outweigh the procompetitive benefits. ${ }^{134}$ Rather than merely "similar," the Section 5 Statement's high-level description of the rule of reason appears to be virtually identical to the long-standing interpretation of the rule of reason. ${ }^{135}$

The rule of reason stands in contrast to per se and presumption of illegality. In the rules versus standards dichotomy, the rule of reason is antitrust law's standards-based framework, whereas presumptive illegality and especially per se illegality are more rules-oriented. ${ }^{136}$ Starting in the

likely to use simpler iterations of the rule of reason sparingly. Ramirez emphasized that the Section 5 Statement is an expression of continuity with the past, rather than a break with it. Ramirez, supra note 128, at 10. In laying out a streamlined version of the rule of reason, Ramirez cites the FTC's "quick look" rule of reason in the context of conduct resembling collusion. Ramirez, supra note 128 , at 8 . This is a telling example. Over the past three decades, the FTC has applied a truncated rule of reason analysis to horizontal restraints on price and non-price competition. See, e.g., Polygram Holding, Inc. v. FTC, 416 F.3d 29, 37 (D.C. Cir. 2005) (affirming FTC's decision that agreements between competitors to restrict price cutting and advertising is inherently suspect). Elsewhere, the FTC has relied on the full-blown rule of reason. See, e.g., McWane, Inc. v. FTC, 783 F.3d 814, 842 (11th Cir. 2015) (upholding FTC's decision that a monopolist's exclusive dealing was illegal under a full rule of reason analysis). Treating it as an affirmation of FTC practice over the past several decades, the Section 5 Statement should be seen as leaving some space for simpler legal standards for collusion-like conduct but requiring full market analysis for mergers, monopolies, and vertical restraints.

131. See Leegin Creative Leather Prods., Inc. v. PSKS, Inc., 551 U.S. 877, 886-87 (2007) (identifying the rule of reason as the standard for determining whether a practice restrains trade and discussing the factors that are considered).

132. United States v. Microsoft Corp., 253 F.3d 34, 58-59 (D.C. Cir. 2001).

133. Id. at 59 .

134. Id.

135. See Section 5 Statement, 80 Fed. Reg. at 57,056 ("[T]he act or practice will be evaluated under a framework similar to the rule of reason, that is, an act or practice challenged by the Commission must cause, or be likely to cause, harm to competition or the competitive process, taking into account any associated cognizable efficiencies and business justifications ....").

136. See generally Daniel A. Crane, Rules Versus Standards in Antitrust Adjudication, 64 WASH. \& LEE L. REV. 49 (2007). 
late 1970s, the courts, in their antitrust decisions, shifted decisively away from rules and toward standards and held that most types of business conduct should be analyzed under balancing tests like the rule of reason. ${ }^{137}$ The federal antitrust agencies have adopted a similar analytical framework, one reliant on fact-driven inquiries, for addressing antitrust concerns in mergers. ${ }^{138}$ The Supreme Court has held that the rule of reason is now the default analytical tool in antitrust cases. ${ }^{139}$ Today, only price fixing, market division, and bid rigging between rivals remain per se illegal. ${ }^{140}$

\section{The Rule of Reason Is Not Equipped to Advance Consumer Welfare}

The rule of reason requires a case-by-case balancing that is beyond the capability of federal antitrust enforcers, let alone generalist courts. For example, how can the FTC or a court credibly balance the short-term loss of price competition from a horizontal merger against the realization of longer-term dynamic efficiencies? ${ }^{141}$ This task calls for "speculative, possibly labyrinthine, and unnecessary"142 analysis and appears to be

137. See, e.g., Weyerhaeuser Co. v. Ross-Simmons Hardwood Lumber Co., 549 U.S. 312,314 (2007) (holding that a two-pronged reasonableness test that applied to predatory pricing claims also applied to predatory bidding actions); State Oil Co. v. Khan, 522 U.S. 3, 10-15 (1997) (reviewing the Supreme Court's previous decisions regarding the rule of reason and highlighting the reluctance to adopt per se rules).

138. See generally U.S. DeP'T of Justice \& Fed. Trade Comm'n, Horizontal Merger GUIDELINES (2010), http://www.justice.gov/atr/public/guidelines/hmg-2010.pdf [https://perma.cc/E623-FVNT] (outlining the analytical techniques used to address antitrust concerns following a merger or acquisition).

139. State Oil Co., 522 U.S. at 10.

140. See Nynex Corp. v. Discon, Inc., 525 U.S. 128, 133-34 (1998) (summarizing the Supreme Court's decisions with respect to horizontal and vertical price-fixing while highlighting its status as per se illegal); see also Palmer v. BRG of Ga., Inc. 498 U.S. 46, 49-50 (1990) (finding that a market division agreement between rivals was illegal "on its face"). Some types of collusion-like behavior have been deemed presumptively illegal, under the so-called quick look test, in multiple Supreme Court and lower court rulings. See, e.g., NCAA v. Bd. of Regents of Univ. of Okla., 468 U.S. 85, 109-10 (1984) (stating that a demonstration of anticompetitive behavior does not need to rely on "a detailed market analysis"); N. Tex. Specialty Physicians v. FTC, 528 F.3d 346, 362-63 (5th Cir. 2008) (finding that a quick-look analysis was an appropriate way to determine the "net anticompetitive effects" were obvious); Polygram Holding, Inc. v. FTC, 416 F.3d 29, 36 (D.C. Cir. 2005) (finding a restraint presumptively unlawful because of obviousness).

141. See generally Maurice E. Stucke, Does the Rule of Reason Violate the Rule of Law?, 42 U.C. DAVIS L. REV. 1375, 1442 (2009) (suggesting that judicial fact-finders are not capable of assigning values to short and long term efficiencies because of feasibility and consistency concerns).

142. Hon. Richard D. Cudahy \& Alan Devlin, Anticompetitive Effect, 95 MinN. L. REv. 59, 87 (2010). 
beyond the capacities of even the most able institutional actors. Before the adoption of the efficiency paradigm, the Supreme Court cited the practical impossibility of measuring and balancing costs and benefits in declining to apply the rule of reason to certain types of business conduct. In United States v. Topco Associates, the Court acknowledged its institutional limitations when asked to make legislative-type determinations:

There have been tremendous departures from the notion of a freeenterprise system as it was originally conceived in this country. These departures have been the product of congressional action and the will of the people. If a decision is to be made to sacrifice competition in one portion of the economy for greater competition in another portion, this too is a decision that must be made by Congress and not by private forces or by the courts. Private forces are too keenly aware of their own interests in making such decisions and courts are ill-equipped and ill-situated for such decisionmaking. To analyze, interpret, and evaluate the myriad of competing interests and the endless data that would surely be brought to bear on such decisions, and to make the delicate judgment on the relative values to society of competitive areas of the economy, the judgment of the elected representatives of the people is required. ${ }^{143}$

In more recent times, Justice Breyer has raised similar administrative objections to applying the rule of reason to resale price maintenance agreements. $^{144}$

While in theory calling for an impossible intellectual inquiry, the rule of reason, in practice, functions as a standard of "de facto legality." ${ }^{145}$ By

143. United States v. Topco Assocs., 405 U.S. 596, 611-12 (1972).

144. See, e.g., Leegin Creative Leather Prods., Inc. v. PSKS, Inc., 551 U.S. 877, 916 (2007) (Breyer, J., dissenting) ("How easily can courts identify instances in which the benefits are likely to outweigh potential harms? My own answer is, not very easily. For one thing, it is often difficult to identify who-producer or dealer-is the moving force behind any given resale price maintenance agreement. Suppose, for example, several large multibrand [sic] retailers all sell resale-price-maintained products. Suppose further that small producers set retail prices because they fear that, otherwise, the large retailers will favor (say, by allocating better shelf space) the goods of other producers who practice resale price maintenance. Who 'initiated' this practice, the retailers hoping for considerable insulation from retail competition, or the producers, who simply seek to deal best with the circumstances they find? For another thing, as I just said, it is difficult to determine just when, and where, the 'free riding' problem is serious enough to warrant legal protection.").

145. See Douglas H. Ginsburg, Vertical Restraints: De Facto Legality Under the Rule of Reason, 60 ANTITRUST L.J. 67 (1991) (analyzing how the rule of reason analysis has been applied by federal courts of appeals to vertical non-price constraints). Judge Posner has similarly described the rule of reason as a "euphemism for nonliability." Richard A. Posner, The Rule of Reason and the Economic Approach: Reflections on the Sylvania Decision, 45 U. CHI.L.REV. 1, 14 (1977). 
endorsing the rule of reason, the FTC has given powerful businesses broad freedom to dominate markets, whether through mergers, exclusionary conduct, or other anticompetitive practices. The rule of reason imposes heavy burdens on plaintiffs and, correspondingly, establishes a strong presumption of legality for even competitively suspect conduct by firms with market power.

In adopting the rule of reason, the FTC practically guaranteed that it would be able to bring few, if any, Section 5 cases. The statistics demonstrate, in practice, that the rule of reason means that the plaintiff almost always loses. A leading study found that, between 2000 and 2009, defendants received a favorable court ruling in more than ninety-five percent of antitrust cases implicating the rule of reason. ${ }^{146}$

In the merger context, a growing body of evidence shows that insisting on rule of reason style analysis comes at a significant cost to consumers. The Horizontal Merger Guidelines assume that mergers generally enhance efficiency. ${ }^{147}$ This pro-merger assumption seems to rest on a thin bed of evidence. In the manufacturing sector, mergers, instead of creating efficiencies, have led to enhanced market power, as seen in higher price-cost markups. ${ }^{148}$ Furthermore, the assumption that markets with low or moderate concentration (as defined by the Horizontal Merger

146. Michael A. Carrier, The Rule of Reason: An Empirical Update for the 21st Century, 16 GeO. MASON L. REV. 827, 828 (2009).

147. See Horizontal MERger Guidelines, supra note 138 , at $\S 10$ ("[A] primary benefit of mergers to the economy is their potential to generate significant efficiencies and thus enhance the merged firm's ability and incentive to compete, which may result in lower prices, improved quality, enhanced service, or new products.").

148. See Bruce A. Blonigen \& Justin R. Pierce, Evidence for the Effects of Mergers on Market Power and Efficiency 24 (Fin. \& Econ. Discussion Series Working Paper No. 2016082,2016 ) (finding significant evidence of increased average markups from M\&A activity in manufacturing industries); Spencer Weber Waller, Corporate Governance and Competition Policy, 18 Geo. MASON L. REv. 833, 873-79 (2011) (discussing sources and studies that suggest "certain categories of mergers destroy shareholder value and do little, if anything, to create meaningful efficiencies or to enhance market competition"). See also Gustavo Grullon, Yelena Larkin \& Roni Michaely, Are U.S. Industries Becoming More Concentrated? 41 (2016) ("This paper documents that over the last 15 years the level of product market concentration in the US has increased across most industries. This phenomenon has been fueled by consolidation of public firms into mega firms. We show that the increase in concentration levels has implications to firm performance, as it affects profitability, investment, and returns to investors. First, the increase in industry concentration levels is associated with remaining firms generating higher profits through higher profit margins. The results suggest that the increase in profit margin cannot be attributed to increased efficiency but rather to increased market power. Second, mergers in concentrated industries enjoy more positive market reactions, consistent with the idea that market power considerations are becoming a key source of value during these corporate events. Finally, firms in concentrated industries experience significant abnormal stock returns, suggesting that considerable portion of the gains accrues to shareholders."). 
Guidelines) are not conducive to collusion ${ }^{149}$ appears empirically suspect. Contrary to this assumption, price fixing and other collusive conduct has been uncovered in many unconcentrated markets. ${ }^{150}$

John Kwoka's research has raised further questions about whether the fact-intensive merger review process promotes consumer welfare. Kwoka's meta-analysis of merger retrospective studies found that the antitrust agencies failed to act against more than sixty percent of the studied mergers that resulted in price increases. ${ }^{151}$ In a separate study, Kwoka found that simple structural presumptions, such as the market share of the merging parties and combined market share of the leading firms, have a high rate of accuracy in predicting which mergers lead to short-term consumer harm. ${ }^{152}$ These findings cast doubt on the need for open-ended, time-consuming investigations of horizontal mergers in already concentrated markets. ${ }^{153}$

\section{The Rule of Reason's Deficiencies Become Even More Acute Under Progressive-Populist Antitrust}

The problems with the rule of reason become only more severe under the antitrust goals articulated by Congress. This progressive-populist philosophy seeks to protect consumers and producers from powerful sellers and purchasers, maintain open markets, and prevent the accumulation of private power. The rule of reason also fails to advance the incipiency standard in Section 5. Even if the FTC had adopted the goals Congress laid out in 1914 in its Section 5 Statement, the rule of reason would foreclose

149. See Horizontal Merger Guidelines, supra note 138, at $§ 5.3$ ("Mergers resulting in unconcentrated markets are unlikely to have adverse competitive effects and ordinarily require no further analysis.").

150. Maurice E. Stucke, Behavioral Economists at the Gate: Antitrust in the TwentyFirst Century, 38 LOY. U. CHI. L.J. 513, 555-56 (2007).

151. John Kwoka, Mergers, Merger Control, and Remedies: A Retrospective ANALYSIS OF U.S. POLICY 155 (2014).

152. See John Kwoka, The Structural Presumption and the Safe Harbor in Merger Review: False Positives, or Unwarranted Concerns? 48 (Ne. Univ. Dep't of Econ., Working Paper, 2016), http://papers.ssrn.com/sol3/papers.cfm?abstract_id=2782152 [https://perma.cc/2KN2-K9SX] (finding that structural presumptions of illegality are highly accurate in identifying anticompetitive mergers under the consumer welfare standard).

153. While appearing to fail consumers, the current merger review process is an important source of income for economists and lawyers who specialize in merger analysis and have experience at one of the federal antitrust agencies. See generally Jesse Eisinger \& Justin Elliott, These Professors Make More Than a Thousand Bucks an Hour Peddling Mega-Mergers, ProPublica (Nov. 16, 2016), https://www propublica.org/article/theseprofessors-make-more-than-thousand-bucks-hour-peddling-mega-mergers [https://perma.cc/UA6V-KC8P] (discussing the high earnings of professors who are hired by large companies to rebut concerns of increased market power from corporate mergers). 
the realization of these aims.

The original aims of the FTC Act are not susceptible to quantification and balancing. How could the FTC balance incommensurable things such as short-term price effects against enhanced corporate power in the political system? The absurdity of this type of balancing is evident on its face. These are qualitative determinations that call for legislative-type judgments, not a futile quantification exercise. The rule of reason compels the FTC to focus its lens narrowly: it must concentrate on quantifiable, short-term harms (from, for example, mergers) and ignore qualitative and longer-term harms in their entirety. ${ }^{154}$

In eschewing per se rules and presumptions in favor of the rule of reason, the FTC also contradicted the incipiency principle of Section 5. In enacting the FTC Act, Congress aspired to prevent monopolies and oligopolies from dominating markets in the first place, rather than restructure them after they had emerged and become entrenched. ${ }^{155}$ This prophylactic, or incipient, purpose recognized that prevention of competitive problems is more effective than curing them after the fact. Congress believed that once a corporation has become a monopolist it may be very difficult, if not impossible, to restructure the firm and restore competitive market conditions.

The current rule of reason practically bars early interdiction against anticompetitive conduct and permits action against dominant firms only in a very limited set of circumstances. Given the hazards of predicting the future, long-term anticompetitive effects are difficult, if not impossible, to prove in court. In insisting on the showing of likely anticompetitive effects, the rule of reason undercuts the incipiency standard. ${ }^{156}$ These effects can be shown only after a corporation's anticompetitive strategy has fulfilled its objective of enhanced market power or, at best, when the strategy is on the cusp of fulfilling its objective. The rule of reason, by requiring the showing of anticompetitive effects, demands that plaintiffs wait and grant anticompetitive conduct the opportunity to blossom and even flourish.

Some antitrust decisions have gone even further in raising the bar for plaintiffs in rule of reason cases. In the area of monopolization, for example, some courts have adopted a restrictive effects-based approach

154. See Stucke, supra note 1, at 620 (suggesting that the rule of reason is not consistent with enforcement of antitrust policy's traditional goals).

155. Averitt, supra note 51, at 243 (discussing comments by members of Congress aspiring to stop monopolies in their infancies).

156. See Allen P. Grunes \& Maurice E. Stucke, Antitrust Review of the AT\&T/T-Mobile Transaction, 64 FED. COMM. L.J. 47, 58 (2011) (explaining how the incipiency standard cannot be honored under an effects-based approach). 
that requires plaintiffs to show that the excluded rival(s) had the capability of providing short-term price competition against the defendant. ${ }^{157}$ In practical terms, under this standard dominant firms can be held liable only for excluding rivals that have comparable cost structures-an unlikely possibility for most new entrants and small rivals. ${ }^{158}$ If excluded rivals are required to show that they are "worthy" of antitrust protection under this cost-based screen, monopolists are given "free reign to squash nascent, albeit unproven, competitors at will." 159

\section{HOW THE FTC CAN HONOR CONGRESSIONAL INTENT AND RESTORE PROGRESSIVE-POPULIST ANTITRUST LAW}

Given its effective lawmaking authority over Section 5, the FTC can still change course and embrace the vision Congress established for Section 5. A critical first step is for the Commission to repudiate the ahistorical, discredited efficiency paradigm. Moreover, many scholars who believe in antitrust enforcement oppose the rule of reason as the primary legal standard. ${ }^{160}$ Chief Justice Roberts has also criticized the rule of reason for its complexity. ${ }^{161}$

In place of the crabbed efficiency vision of a once expansive body of law, the FTC should look to the goals expressed by the members of Congress and Senators that created it: the protection of consumers and producers from firms with market power, the preservation of open markets, and the dispersal of private economic and political power. Even a century after the FTC's founding, these goals (a "citizen interest" rather than a

157. See Cascade Health Sols. v. PeaceHealth, 515 F.3d 883, 909 (9th Cir. 2008) (discussing the primary "anticompetitive danger" posed by "multi-product bundled discount[s]" and the requirements a plaintiff challenging the discount must meet); see also Andrew I. Gavil, Exclusionary Distribution Strategies by Dominant Firms: Striking a Better Balance, 72 ANTITRUST L.J. 3, 59-60 (2004) (laying out deficiencies for the "equally efficient competitor" standard while suggesting it "could harm consumer welfare").

158. See, e.g., Einer Elhauge, Defining Better Monopolization Standards, 56 STAN. L. REv. 253, 321 (2003) (discussing means of constraining rival efficiency without ever driving them out of the market).

159. United States v. Microsoft Corp., 253 F.3d 34, 79 (D.C. Cir. 2001)

160. E.g., Stucke, supra note 141; Cudahy \& Devlin supra note 142.

161. See F.T.C. v. Actavis, Inc., 133 S. Ct. 2223, 2245 (2013) (Roberts, C.J., dissenting) ("[A]lthough the question posed by this case is fundamentally a question of patent law-i.e., whether Solvay's patent was valid and therefore permitted Solvay to pay competitors to honor the scope of its patent-the majority declares that such questions should henceforth be scrutinized by antitrust law's unruly rule of reason. Good luck to the district courts that must, when faced with a patent settlement, weigh the 'likely anticompetitive effects, redeeming virtues, market power, and potentially offsetting legal considerations present in the circumstances."'). 
"consumer welfare" standard) ${ }^{162}$ are as relevant as ever, and arguably even more so today. ${ }^{163}$ The proposed interpretation would follow a venerable canon of statutory interpretation, looking to the legislative history of a law to articulate the meaning of general statutory text, ${ }^{164}$ and would be much more defensible than consulting the dated economic musings of legal scholars for guidance.

To advance the citizen interest standard, the FTC should interpret Section 5 to cover a range of high risk conduct, some of which is treated very leniently at present. Specifically, the FTC should establish presumptions of illegality for mergers in concentrated markets, certain types of conduct by firms with market power, and vertical restraints that limit retail competition and challenge durable or otherwise harmful possession of market power. Simpler and stronger doctrine must be accompanied by simpler and stronger remedies for Section 5 violations. In remedying anticompetitive behavior, the FTC should generally favor onetime structural remedies over complicated behavioral fixes.

\section{A. The FTC Should Anchor Section 5 in the Congressionally Expressed Goals of the Statute}

Before specific legal rules can be formulated, the FTC must revisit the goals of antitrust law in general and Section 5 in particular. In helping overthrow the historical understanding of antitrust, Robert Bork himself recognized that the identification of the goals of the legal regime is the essential first step. He wrote that one must first ask, "What is the point of the law - what are its goals? Everything else follows from the answer we give." ${ }^{165}$ Bork looked to the legislative histories of the antitrust statutes and incorrectly claimed that they establish allocative efficiency as the only goal of antitrust enforcement. ${ }^{166}$

162. Khan \& Vaheesan, supra note 9 , at 276.

163. See Zephyr Teachout \& Lina Khan, Market Structure and Political Law: A Taxonomy of Power, 9 DuKE J. CON. L. \& PuB. Pol'y 37, 41 (2014) (describing how large corporations have "(1) the power to set policy, (2) the power to regulate, and (3) the power to tax").

164. E.g., Dole v. United Steelworkers of Am., 494 U.S. 26, 35, 40 (1990) (applying "traditional tools of statutory construction" including review of legislative history). One common application of Chevron looks beyond statutory text and examines legislative history to determine whether a statute is ambiguous. Jack M. Beermann, End the Failed Chevron Experiment Now: How Chevron Has Failed and Why It Can and Should Be Overruled, 42 ConN. L. REv. 779, 818 (2010). Under this less deferential formulation of Chevron, the proposed interpretation of Section 5 would still rest on a solid legal basis, whereas the efficiency interpretation would not. See supra Part II.A.

165. Robert H. Bork, The Antitrust PARAdox 50 (1978).

166. Id. at 9 . 
The efficiency or consumer welfare goals that have dominated antitrust for the past two generations neither reflect the objectives of Congress nor address the structural problems in today's economy. Congress, in creating the FTC, had a number of aims. To be sure, the protection of consumers was an aim, but it was only one of several aims. The Congress that enacted the FTC Act sought to protect consumers, producers, competitors, and political institutions from concentrated private power. ${ }^{167}$ These goals are not just a historical artifact. The growing public concerns about monopoly and oligopoly in the American economy extend beyond higher consumer prices. ${ }^{168}$ They also include diminished opportunities for entrepreneurs due to closed markets and the subversion of democracy by businesses with market power. In short, the fears being expressed today-increasing concentration, ${ }^{169}$ fewer new businesses, ${ }^{170}$ increasing wealth inequality, ${ }^{171}$ and more profits concentrated in fewer firms ${ }^{172}$ - bear a striking resemblance to those that Congress voiced more than a century ago.

The FTC must renounce the narrow efficiency paradigm and reembrace the broad vision of Congress. The efficiency paradigm is an ahistorical innovation developed in the 1960s and 1970s. It reflects the empirically-deficient ideologies of some economists and lawyers, not the goals of Congress in 1914 or 1890, not the goals when the Clayton Act was amended after World War II, and not even the implicit goals of Congress when the FTC Act was amended in the 1980s. ${ }^{173}$ Perpetuating an ill-

167. See supra part II.A.

168. See, e.g., Warren, supra note 3, at 2-4 (blaming market concentration for the lack of consumer choice, barriers to competition, the dearth of small businesses, "concentrated political power," and the decline of the middle class).

169. See e e.g., COUNCIL OF ECON. ADVISERS, BENEFITS OF COMPETITION AND INDICATORS OF MARKET POWER 4 (2016) (noting that increased industry concentration is an indication of lower competition).

170. See Ian Hathaway \& Robert E. Litan, What's Driving the Decline in the Firm Formation Rate? A Partial Explanation, BRoOKIngs InSTITUTION (2014), http://www.brookings.edu/wp-content/uploads/2016/06/driving_decline_firm_formation_ rate_hathaway_litan.pdf [https://perma.cc/3BFX-V6WN].

171. See generally ThOMAs PiketTy, CAPITAL In THE TwENTY-First CENTURY (2013).

172. See supra at note 6 .

173. See May, supra note 73, at 286-300 (citing traditional economic theory as the driving force behind antitrust laws, rather than firm efficiency). Eleanor M. Fox, The Modernization of Antitrust: A New Equilibrium, 66 CORNELl L. Rev. 1140, 1150 (1981) ("The legislative history of the Celler-Kefauver Amendment speaks clearly and overwhelmingly of the social evils of 'concentration.' The legislators who supported the Amendment did so on grounds of the dangers of increasing economic concentration, not on grounds of the virtues of efficiency."); Hurwitz, supra note 30, at 263 (explaining that Congress amended the FTC's consumer protection authority to comply with the logic of neoclassical economics but did not cabin its competition authority in the same manner). 
defined efficiency goal with the rule of reason subverts the intentions of Congress. By embracing efficiency, the FTC has allowed what Congress feared to come to fruition: oligopolistic and monopolistic markets that harm consumers, restrict entry, and undermine democratic institutions. The FTC must anchor its advocacy, enforcement, and rulemaking in the everrelevant aims of Congress: 1) the protection of consumers and sellers (such as farmers) from wealth transfers due to firm market power, 2) the preservation of open markets, and 3) the dispersal of private economic and political power.

\section{B. The FTC Should Establish Presumptions Against Competitively Suspect Conduct}

To advance Congress's goals in enacting Section 5, the FTC should establish presumptions of illegality for competitively suspicious conduct. Continued reliance on the rule of reason means continued antitrust dormancy. Just consider the death of Section 2 (anti-monopoly) enforcement by the Department of Justice ("DOJ"). ${ }^{174}$ While this decline in the number of DOJ Section 2 cases has multiple causes, the pro-defendant legal standards are likely a major factor. ${ }^{175}$ If the FTC is to effectuate Congressional intent, it must reject the rule of reason and adopt a series of presumptions of illegality for conduct that can injure consumers and producers, exclude rivals, and concentrate private power. The FTC already applies presumptions of illegality to conduct resembling collusion. ${ }^{176} \mathrm{It}$, however, should go further and apply presumptions to a much broader set of competitively suspect behavior.

174. Compare Antitrust Division, Workload Statistics FY 2006-2015 5, https://www.justice.gov/atr/file/788426/download [https://perma.cc/FGJ7-9H4Q] (showing that only one monopoly case was filed in court between 2006 and 2015), with ANTITRUST Division, WORKLOAD STATISTICS FY 1970-1979 4, https://www.justice.gov/ sites/default/files/atr/legacy/2009/06/09/215792.pdf [https://perma.cc/M6VU-AVTR] (indicating that fifteen monopoly and oligopoly cases were filed in 1971 alone).

175. Herbert Hovenkamp, The Obama Administration and Section 2 of the Sherman Act, 90 B.U. L. REV. 1611, 1613 (2010). While plaintiffs face unfavorable legal standards in monopolization cases, some have still won important victories in this trying legal environment. See, e.g., ZF Meritor, LLC v. Eaton Corp., 696 F.3d 254, 303 (3rd Cir. 2012) (affirming jury verdict finding defendant liable for anticompetitive exclusive dealing); Spirit Airlines, Inc. v. Nw. Airlines, Inc., 431 F.3d 917, 953 (6th Cir. 2005) (vacating district court's grant of summary judgment for defendant accused of predatory pricing).

176. See, e.g., Polygram Holding, Inc. v. FTC, 416 F.3d 29, 37 (D.C. Cir. 2005) (affirming FTC's decision that agreements between competitors to restrict price cutting and advertising is inherently suspect); N. Tex. Specialty Physicians v. FTC, 528 F.3d 346, 36263 (5th Cir. 2008) (concluding that "quick-look analysis" was appropriate for evaluating price fixing-like conduct). 
The FTC has flexibility over how to develop these legal standards. ${ }^{177}$ It can create them through case-by-case adjudication, which has been the agency's primary policymaking vehicle over the past few decades. ${ }^{178}$ It can also establish Section 5 antitrust legal standards through rulemakings. ${ }^{179}$ Also, the choice of whether to proceed through adjudication or rulemaking does not affect the level of deference that courts would accord to an FTC interpretation of Section 5. Interpretations made through either adjudication or rulemaking are generally entitled to Chevron deference. ${ }^{180}$

On the competition side, the FTC's rulemaking authority has not been changed in the multiple post-1970s Congressional amendments to the FTC Act. ${ }^{181}$ The FTC can issue competition rules under the standard notice-andcomment procedures under the Administrative Procedure Act. An FTC competition rule would not have to comply with the more onerous Magnuson-Moss Act procedures required for consumer protection rules. ${ }^{182}$

As to specific practices, the FTC should hold mergers in concentrated markets, conduct with exclusionary potential by dominant and neardominant firms, and vertical restraints on retail and other distributional competition to be presumptively illegal. These types of conduct can harm consumers and producers, unfairly exclude rivals and new entrants, and concentrate private power. To prevent these harms instead of correct them after the fact, the FTC should establish presumptions of illegality for a range of competitively problematic conduct.

By replacing the costly and time-consuming rule of reason and other open-ended standards, ${ }^{183}$ these presumptions of illegality would discourage anticompetitive conduct and establish quasi-bright lines as to permissible

177. NLRB v. Bell Aerospace Co. Div. of Textron Inc., 416 U.S. 267, 294 (1974).

178. Hayley Tsukayama, FTC Chairwoman Edith Ramirez Chats About Privacy, Security and Why She's At CES, WASH. Post (Jan. 6, 2016), https://www.washingtonpost.com/news/the-switch/wp/2016/01/06/ftc-chairwoman-edithramirez-chats-about-privacy-security-and-why-shes-at-ces/?utm_term=.df0f4f06b860 [https://perma.cc/6LKD-GA7U] (describing FTC as "mainly a law enforcement agency").

179. The D.C. Circuit has held that the FTC has rulemaking authority under Section 5. Nat'l Petroleum Refiners Ass'n v. FTC, 482 F.2d 672, 697-98 (D.C. Cir. 1973).

180. See United States v. Mead Corp., 533 U.S. 218, 229-30 (2001) ("We have recognized a very good indicator of delegation meriting Chevron treatment in express congressional authorizations to engage in the process of rulemaking or adjudication that produces regulations or rulings for which deference is claimed.").

181. See Hurwitz, supra note 30, at 233-37 (tracing the FTC's Section 5 rulemaking power from National Petroleum Refiners Ass'n through the 1994 FTC Reauthorization).

182. While Congress has modified the FTC's rulemaking power under its consumer protection authority since 1973, it has not modified this power for the Commission's antitrust authority. See Hurwitz, supra note 30, at 251 ("Congress has expressly acknowledged, discussed, and declined to alter this power in the context of Section 5's prohibition against unfair methods of competition.").

183. Stucke, supra note 141, at 1461-63. 
and impermissible conduct. ${ }^{184}$ At the same time, these presumptions would not amount to categorical prohibitions of the enumerated practices. Rather, they would shift the burden of proof to firms that engage in competitively suspicious behavior and invite them to rebut the presumption of illegality through the showing of credible business justifications.

\section{Mergers}

Mergers in concentrated markets have serious anticompetitive potential. These corporate consolidations can raise consumer prices by eliminating head-to-head competition and facilitating both express and implicit collusion. ${ }^{185}$ Mergers can also enhance the consolidating entities' power to exclude rivals. ${ }^{186}$ While vertical mergers are assumed to be less harmful than horizontal mergers, they can also have serious anticompetitive effects. For example, in markets with strong network effects, a dominant firm in one market can acquire a firm in an adjacent market, foreclose rivals from this market, and dictate the long-term development of the entire sector. ${ }^{187}$ Furthermore, the concentration of private power should not be ignored. Mergers of all kinds-horizontal, vertical, or conglomerateconcentrate the control of economic and political power in fewer hands.

To prevent the harms from horizontal mergers, the FTC should use its Section 5 authority to adopt a strong presumption of illegality for mergers in concentrated markets. The FTC should look to Supreme Court precedent for guidance here. The Supreme Court has held that a horizontal merger that would result in the merged entity having a share of greater than thirty percent is presumptively illegal. ${ }^{188}$ The Court intimated that a merger involving parties with a combined market share of twenty percent may also be presumptively illegal. ${ }^{189}$ Philadelphia National Bank arose in the

184. See generally Arndt Christiansen \& Wolfgang Kerber, Competition Policy with Optimally Differentiated Rules Instead of "Per Se Rules vs Rule of Reason", 2 J. COMPETITION L. \& ECON. 215 (2006) (favoring rule differentiation over case-by-case adjudication). Proceedings under the proposed presumptions would not necessarily be as expeditious and straightforward as those under per se rules because, in some cases, market definitions and efficiencies would call for fact-intensive inquiries. Stucke, supra note 141, at $1461-62$.

185. HORIZONTAL MERGER GUIDELINES, supra note 138, at $\S \S 6-7$.

186. HORIZONTAL MERGER GUIDELINES, supra note 138, at $\$ 1$.

187. See, e.g., Marc Jarsulic et al., Reviving Antitrust: Why Our Economy Needs a Progressive Competition Policy, CTR. FOR AM. PROGRess 16 (June 2016), https://cdn .americanprogress.org/wp-content/uploads/2016/06/28143212/

RevivingAntitrust.pdf [https://perma.cc/NVY7-88QP] (suggesting that studies showed increased opportunities for anticompetitive effects following vertical integration).

188. United States v. Phila. Nat'l Bank, 374 U.S. 321 , 364 (1963).

189. Id. 
context of Section 7 of the Clayton Act, not Section 5. ${ }^{190}$ The FTC should recognize the broader substantive reach of the Section 5 and adopt a presumption of illegality at no higher than the twenty percent threshold. ${ }^{191}$

In the area of vertical mergers, the FTC should also establish a comparable presumption of illegality. The Supreme Court has not established bright lines concerning vertical mergers, as it has with horizontal mergers. ${ }^{192}$ Although the FTC does not have comparable precedential guidance in this area, it can use its investigatory and research powers to understand the dynamics of vertical mergers and determine the point at which vertical mergers threaten to raise prices and exclude rivals. At a minimum, the FTC should deem vertical acquisitions by dominant or near-dominant firms to be presumptively illegal, regardless of the size of the acquired firm. In addition, a merger between a firm with a thirty percent or greater market share in one market and another firm with a thirty percent or greater share in an adjacent market could be subject to a presumption of illegality. ${ }^{193}$

Under the proposed presumptions, parties would have the opportunity to rebut a prima facie case of illegality through the showing of business justifications. Parties to these combinations could rebut the presumption by showing that the merger is the least restrictive means to achieve a particular legitimate business goal. For example, they could demonstrate that the merger is necessary to develop new product lines. The presumption would be strong and difficult to rebut. If the acquirer could reasonably achieve its purported objectives through means less threatening to competition, such as internal expansion, the presumption of illegality would not be overcome. Conversely, if the acquirer can establish that the merger is the least restrictive way to realize the objectives, it could rebut the presumption of illegality.

190. Id. at 335 .

191. See Stucke, supra note 150, at 555-56 (observing collusion in many moderately concentrated and unconcentrated markets).

192. See Brown Shoe Co. v. United States, 370 U.S. 294, 328 (1962) ("Since the diminution of the vigor of competition which may stem from a vertical arrangement results primarily from a foreclosure of a share of the market otherwise open to competitors, an important consideration in determining whether the effect of a vertical arrangement 'may be substantially to lessen competition, or to tend to create a monopoly' is the size of the share of the market foreclosed. However, this factor will seldom be determinative.").

193. See, e.g., Guidelines on the Assessment of Non-Horizontal Mergers under the Council Regulation on the Control of Concentrations Between Undertakings, 2008 O.J. (C 265) 6,9 ("The Commission is unlikely to find concern in non-horizontal mergers, be it of a coordinated or of a non-coordinated nature, where the market share post-merger of the new entity in each of the markets concerned is below $30 \%$ and the post-merger $\mathrm{HHI}$ is below 2000.”). 


\section{Dominant Firm Conduct}

Dominant and would-be dominant firms can resort to a variety of practices to exclude competitors while maintaining or enhancing their market power. Monopolists and near-monopolists can use exclusive dealing and market share penalties or rebates to prevent rivals from accessing consumers or essential distribution channels. ${ }^{194}$ They can also resort to predatory pricing whereby they use short periods of below-cost pricing to exclude competitors and deter possible entrants from participating in the market. ${ }^{195}$ In addition, they can engage in tyingconditioning the purchase of a product in which they have monopoly power on the purchase of a related product in a competitive market as a means of extending their market power into this second market. ${ }^{196}$ While exclusionary tactics cannot be cataloged exhaustively, these are some of the anticompetitive practices that have been used over time in a variety of industries.

For dominant and near-dominant firms, the FTC should establish presumptions of illegality for particular types of conduct with exclusionary potential. To further the incipiency standard of Section 5, these special presumptions should apply to both firms on the threshold of dominance, and firms with established market dominance. A market share greater than or equal to forty percent would seem to be a reasonable cutoff. For firms in this category, the FTC should adopt presumptions of illegality for, among other practices, exclusive dealing, market-share discounts, and predatory pricing. Dominant and near-dominant firms that engaged in these practices would be presumptively in violation of Section 5. The FTC would be following the logic of the existing Sherman Act approach to tying. ${ }^{197}$

194. See Steven C. Salop, Economic Analysis of Exclusionary Vertical Conduct: Where Chicago Has Overshot the Mark, in How the Chicago School Overshot THE MARK 141, 150 (Robert Pitofsky ed., 2008) (suggesting that competition for exclusives creates competitive constraints on market participants and can lead to the exclusion of rivals).

195. See Sandeep Vaheesan, Reconsidering Brooke Group: Predatory Pricing in Light of the Empirical Learning, 12 BERKELEY BUS. L.J. 81, 84-94 (2015) (discussing suspected and confirmed predatory pricing practices by dominant firms in the twentieth century).

196. Einer Elhauge, Tying, Bundled Discounts, and the Death of the Single Monopoly Profit Theory, 123 HARV. L. REV. 397, 417-20 (2009).

197. See, e.g., Jefferson Parish Hosp. Dist. No. 2. v. Hyde, 466 U.S. 2, 15-18 (1984) (stating that the validity of a tying arrangement should be determined by assessing whether consumers are forced to accept the tying arrangement through the sellers' market power); see also Collins Inkjet Corp. v. Eastman Kodak Co., 781 F.3d 264, 271-72 (6th Cir. 2015) (citations omitted) ("The tie falls foul of antitrust law if the seller has appreciable economic power in the tying product market and the arrangement affects a substantial volume of commerce in the tied market.... A tying arrangement that falls foul of these criteria and lacks a valid business justification is anticompetitive because it tends to force more efficient 
A presumption of illegality based on a market share would recognize that the competitive implications of a particular form of conduct depend on the power of the entity practicing it. For example, below-cost pricing by a firm with a fifty percent share of the market has radically different competitive implications than below-cost pricing by a recent entrant with just five percent of the market. ${ }^{198}$ The former has serious exclusionary potential, while the latter is much more likely to be competitively benign. ${ }^{199}$

Similar logic distinguishes exclusive dealing practiced by a monopolist or other dominant firm from exclusive dealing practice by a firm with a small market share. The FTC has already recognized the competitive threat of monopolists' use of exclusive arrangements with distributors. Between 2008 and 2016, the FTC brought many enforcement actions against monopolists that insisted on exclusivity arrangements with distributors. $^{200}$ The Commission recognized that under these circumstances, exclusive dealing threatened to exclude competitors and injure consumers in the short and long run. ${ }^{201}$ Given this enforcement record and collective body of evidence, exclusive dealing by dominant firms appears to be an obvious target for further policy development by the FTC. A future FTC should establish, through either an enforcement action or rulemaking, that exclusive dealing by dominant and near-dominant firms is presumptively illegal under Section 5 .

Under these presumptions of illegality, firms would have the opportunity to present business justifications to rebut the FTC's prima facie case of anticompetitive conduct. They could overcome the presumption by showing that the practice is necessary to achieve a legitimate business aim

competitors out of the tied product market.").

198. See Eastman Kodak Co. v. Image Tech. Servs., Inc., 504 U.S. 451, 488 (1992) (Scalia, J., dissenting) ("Behavior that might otherwise not be of concern to the antitrust laws-or that might even be viewed as procompetitive-can take on exclusionary connotations when practiced by a monopolist.").

199. Vaheesan, supra note 195, at 99-100.

200. E.g., McWane, Inc. v FTC, 783 F.3d 814, 842 (11th Cir. 2015) (affirming FTC decision that producer of domestic pipe fittings used exclusive dealing to improperly exclude competing domestic manufacturers of ductile iron pipe fittings); In re IDEXX Labs., Inc., 155 F.T.C. 241, 242 (2013) (alleging that the respondent used exclusive dealing to foreclose market access to rival manufacturers of veterinary diagnostic products); In re Pool Corp., F.T.C. No. 101-0115, 2012 WL 159752, at *6-7 (Jan. 10, 2012) (settling allegations the respondent used exclusive dealing to marginalize rival pool product distributors); In re Transitions Optical, Inc., 149 F.T.C. 1281, 1325 (2010) (settling allegations that respondent's exclusive dealing with lens casters foreclosed rival photochromic lens makers from market).

201. See, e.g., In re Transitions Optical, Inc., 149 F.T.C. at 1317 (foreclosure of "rivals from key distribution channels" reduced competition and led to "higher prices, lower output, reduced innovation and diminished consumer choice"). 
and that the practice is the least restrictive means of doing so. For example, a firm with a market share in excess of forty percent that engaged in a period of below-cost pricing could rebut the presumption of illegality by showing that this pricing practice was necessary and the least restrictive means of implementing a learning-by-doing strategy to lower long-term costs of production. ${ }^{202}$ The presumption would be strong and could only be overcome through the presentation of specific, credible evidence, not just assertions about theoretical efficiencies.

\section{Vertical Restraints}

Distributional restraints have immediate and long-term anticompetitive effects, lack empirically validated business justifications, and so should be subject to a presumption of illegality under Section 5 . Practices such as resale price maintenance and exclusive territories limit intrabrand competition, raise consumer prices, and impede entry in the retail sector. The justifications for these restraints are largely theoretical and not applicable to the vast majority of consumer products.

Resale price maintenance ("RPM"), by design, restricts competition at the retail level, raises consumer prices, and impedes the emergence of new retailers and retail formats. It sets a floor on retail prices and prevents retailers from competing freely on price. ${ }^{203}$ The harms extend beyond higher retail prices in the short run. With diminished price competition at the retail level, retailers are likely to put less pressure on upstream distributors and manufacturers to cut wholesale prices. ${ }^{204}$ Resale price maintenance regimes also inhibit the growth of new innovative retail models because sellers with a lower cost structure cannot compete freely on price and share their cost advantages with consumers. ${ }^{205}$

The procompetitive justifications offered for resale price maintenance are theoretical and have limited applicability to real-world retail markets. The principal rationale is the need to protect full-service retailers offering costly point-of-sale support from the "free-riding" of lower-cost, no-service

202. See Patrick Bolton, Joseph F. Brodley \& Michael H. Riordan, Predatory Pricing: Strategic Theory and Legal Policy, 88 GEO. L.J. 2239, 2280-81 (1999) (outlining several viable proof of efficiencies defenses that could rebut the presumption of illegality).

203. Marina Lao, Free Riding: An Overstated, and Unconvincing, Explanation for Resale Price Maintenance, in How THE CHICAGo SCHOOL OverSHOT THE MARK 196, 210 11 (Robert Pitofsky ed., 2008).

204. Robert L. Steiner, How Manufacturers Deal with the Price-Cutting Retailer: When Are Vertical Restraints Efficient?, 65 ANTITRUST L.J. 407, 441-42 (1997).

205. Marina Lao, Resale Price Maintenance: The Internet Phenomenon and Free Rider Issues, 55 ANTITRUST BULL. 473, 509 (2010). 
retailers that compete through aggressive discounting. ${ }^{206}$ At oral arguments in Leegin Creative Leather Products, Inc. v. PSKS, Inc., Justice Breyer noted that this theoretical justification is decades-old and yet continues to have very limited empirical support. ${ }^{207}$ Notwithstanding this dearth of evidentiary support for the free riding theory, the Supreme Court, in its decisions liberalizing the law on vertical restraints, has stressed the need to protect against free riding at the retail level..$^{208}$

While intangible promotional services can be important, they are not relevant for most consumer goods and can be provided through effectiveand less restrictive-alternatives for goods that require special sales support. As a practical matter, few goods require retail services. ${ }^{209}$ The growth of online commerce has increased the availability of product information and diminished the need for retail sales support. ${ }^{210}$ Antitrust policy should not be made on a theory that is applicable to a very small subset of manufacturers and products. And for goods that require sales support, superior alternatives exist. At the retail level, one option is promotional allowances to retailers that agree to offer a discrete bundle of services. For instance, a manufacturer of a complex product can pay retailers a fee on the condition that they provide product demonstrations. ${ }^{211}$ A manufacturer can also restrict the distribution of its products to, for example, full-service retailers that provide extensive sales support. ${ }^{212}$

Given the guaranteed loss of retail competition from vertical restraints and improbability of offsetting consumer benefits, ${ }^{213}$ the FTC should hold resale price maintenance and similar practices such as exclusive territories ${ }^{214}$ to be presumptively illegal under Section 5. This standard

206. John B. Kirkwood, Rethinking Antitrust Policy Toward RPM, 55 AnTITRUST BulL. 423, 443-48 (2010).

207. Leegin Creative Leather Prods., Inc. v. PSKS, Inc., 551 U.S. 877, 877 (2007); Transcript of Oral Argument at 12-13, Leegin Creative Leather Prods., Inc. v. PSKS, Inc., 551 U.S. 877 (2007) (No. 06-480).

208. Leegin, 551 U.S. at 891-92; Bus. Elecs. Corp. v. Sharp Elecs. Corp., 485 U.S. 717, 725 (1988).

209. Lao, supra note 203, at 201.

210. Marina Lao, Resale Price Maintenance: The Internet Phenomenon and Free Rider Issues, 55 ANTITRUST BULL. 473, 482 (2010).

211. Warren S. Grimes, The Path Forward After Leegin: Seeking Consensus Reform of the Antitrust Law of Vertical Restraints, 75 ANTITRUST L.J. 467, 478 (2008).

212. Kirkwood, supra note 206, at 447.

213. See, e.g., Alexander MacKay \& David Aron Smith, The Empirical Effects of Minimum Resale Price Maintenance 3 (Univ. of Chi. Kilts Ctr. for Mktg., Paper No. 2-006, 2014) (finding that resale price maintenance is, on the whole, anticompetitive, resulting in higher prices and lower output).

214. William S. Comanor, Vertical Arrangements and Antitrust Analysis, 62 N.Y.U. L. REV. 1153, 1160 (1987). 
would reflect the high risks of harm from these practices. At the same time, businesses should be allowed to rebut the presumption by offering pro-consumer justifications. Specifically, they should be entitled to overcome the presumption by showing that the restraint is reasonably necessary and the least restrictive alternative to achieve a beneficial end, such as the provision of point-of-sale services. For instance, book publishers may be justified in instituting resale price maintenance. Brickand-mortar sellers provide readers a distinctive opportunity to browse a wide selection of titles and subjects and receive recommendations from store staff, which may be services on which online sellers such as Amazon can free ride. ${ }^{215}$

\section{The FTC Should Challenge Durable or Otherwise Seriously Harmful Monopolies and Oligopolies}

In addition to policing against the emergence of monopolistic and oligopolistic market structures, the FTC should challenge possession of durable or otherwise harmful monopoly and oligopoly power. Given the existing levels of concentration in the economy, ${ }^{216}$ a purely preventative approach is not likely to be sufficient to tackle the problems of monopoly and oligopoly. Durable market power can inflict substantial harm on the public-most obviously through prolonged pricing above competitive levels or depressed wages for workers and prices for producers. Monopoly and oligopoly power in the market for necessities, even when it is not enduring, can similarly result in significant harm. In addition, a monopoly represents a dramatic example of the concentration of private power and resources in which a single entity controls an entire market not just today, but perhaps for an extended period of time. In interpreting Section 5 to apply to these instances of harmful market power, the FTC would depart from existing monopolization doctrine in an important way-it would not require the showing of bad acts on the part of the firm or firms with market power.

Under present Sherman Act precedent, monopoly power alone is not

215. See Julie Bosman, Book Shopping in Stores, Then Buying Online, N.Y. TIMES (Dec. 4, 2011), https://mediadecoder.blogs.nytimes.com/2011/12/04/book-shopping-in-storesthen-buying-online/?ref=todayspaper\&_r=0 [https://perma.cc/5AFJ-252M] ("Thirty-nine percent of people who bought books from Amazon in the same period said they had looked at the book in a bookstore before buying it from Amazon, the survey said. As frustrated bookstore owners see it, the practice allows customers to take advantage of the stores' careful selection of books, staff recommendations and warm atmosphere - all while spending their money elsewhere.").

216. ECONOMIST, supra note 6. 
illegal even though it can inflict substantial harm on the public. To invite legal liability, monopoly power must be accompanied by bad acts, such as predatory pricing. ${ }^{217}$ This principle is a long-standing norm in antitrust case law, preceding the Chicago School reinterpretation. ${ }^{218}$ Yet, the harm from market power is no less real even in the absence of bad conduct. For example, enduring market power can amount to the public paying a private tax for a product for an extended period of time. ${ }^{219}$ In the market for necessities, such as electricity, ${ }^{220}$ even short periods of market power can result in massive wealth transfers from consumers to businesses. The exercise of market power in a number of pharmaceutical markets is the latest illustration of the real harm inflicted on consumers. ${ }^{221}$

The doctrinal requirement of bad conduct can be a costly and unnecessary diversion. In monopolization cases, the aim of the litigation may be to restructure a noncompetitive market-not merely prohibit particular bad acts. ${ }^{222}$ By requiring evidence of anticompetitive behavior, Section 2 precedent has required the devotion of substantial resources to a secondary issue and led to interminable and costly litigation, resembling "an epic Russian film with a bewildering cast of hundreds, byzantine procedural complexity, and elaborate records." 223 The landmark monopolization suits against AT\&T and IBM embody the problems associated with a conduct-focused approach. Litigants spent huge sums of money and years trying to resolve whether the defendants had undertaken improper acts, when the purpose of the cases was to remedy the persistent monopolistic structure of the telecommunications and computer markets. ${ }^{224}$

The FTC should challenge persistent or otherwise harmful market

217. Verizon Commc'ns, Inc. v. Law Offices of Curtis V. Trinko, LLP, 540 U.S. 398, 407 (2004).

218. United States v. Grinnell Corp., 384 U.S. 563, 570-71 (1966).

219. Alfred F. Dougherty, Jr. et al., Elimination of the Conduct Requirement in Government Monopolization Cases, 37 WASH. \& LEE L. REV. 83, 87 (1980).

220. Frank A. Wolak, Measuring Unilateral Market Power in Wholesale Electricity Markets: The California Market, 1998-2000, 93 AM. ECON. REV. 425, 430 (2003).

221. See, e.g., Carolyn Y. Johnson \& Catherine Ho, How Mylan, the Maker of EpiPen, Became a Virtual Monopoly, WAsh. Post (Aug. 25, 2016), https:/www.washingtonpost.com/business/economy/2016/08/25/7f83728a-6aee-11e6-ba325a4bf5aad4fa_story.html [https://perma.cc/RPJ7-MXDP] (discussing the harm of current monopolies to the pharmaceutical industry).

222. See Maurice E. Stucke, Should the Government Prosecute Monopolies?, 2009 U. Ill. L. Rev. 497, 546 (noting the historical preference in the United States for "maintaining competitive market structures, rather than regulatory dictates").

223. John J. Flynn, Do the Proposals Make Any Sense from a Business Standpoint? Pro No-Conduct Monopoly: An Assessment for the Lawyer and Businessman, 49 ANTITRUST L.J. 1255,1264 (1980).

224. Id. at 1265 . 
power under its Section 5 authority even in the absence of bad conduct. Section 5 should be interpreted to reach these structural problems directly when a persistent lack of competition or substantial public harm can be shown. That said, no-fault market power is a departure from existing antitrust doctrine and should be applied judiciously. ${ }^{225}$ The required factual showing should be significant and should only be satisfied in exceptional cases in which the harm to the public is enduring or otherwise severe.

The FTC should establish two legal standards for no-fault market power. First, the FTC should show durable monopoly power that has not been diminished through new entry, technological change, or reduced demand for the product. Second, and alternatively, the FTC should show market power that inflicts substantial monetary harm on the public because it affects the markets for necessities in which demand is highly inelastic. Examples include the market power that has been witnessed in some electricity $^{226}$ and pharmaceutical markets. ${ }^{227}$ Furthermore, satisfying this requirement of persistent or substantially harmful market power should establish only a presumption of illegality. Parties should have the opportunity to rebut this presumption by demonstrating that the monopoly power is, for instance, the product of operational efficiencies that would be lost under a more competitive market structure or was the necessary spur to innovate, as in certain pharmaceutical markets. ${ }^{228}$

225. The European Commission's careful targeting of exploitative pricing under the abuse of dominance standard can inform FTC action against durable monopolies. Working Party No. 2 on Competition and Regulation, at 10, WD (2011) 54 (Oct. 14, 2011), http://ec.europa.eu/competition/international/multilateral/2011_oct_excessive_prices.pdf [https://perma.cc/87X5-GN96] ("The case law... shows that the Commission and European Courts addressed the question of excessive prices only in markets with an entrenched dominant position where entry and expansion of competitors could not be expected to ensure effective competition in the foreseeable future.").

226. Wolak, supra note 220, at 430. See also Severin Borenstein, James B. Bushnell \& Frank A. Wolak, Measuring Market Inefficiencies in California's Restructured Wholesale Electricity Market, 92 AM. ECON. REV. 1376, 1398 (2002) (finding that between the summers of 1998 and 2000, oligopoly rents "increased by an order of magnitude, from about $\$ 425$ million to $\$ 4.44$ billion").

227. Johnson \& Ho, supra note 221. The United Kingdom's Competition and Markets Authority has brought multiple no-fault monopoly actions against pharmaceutical companies. E.g., Press Release, Competition \& Mkts. Auth., Pharm. Co. Accused of Overcharging NHS (Dec. 16, 2016), https://www.gov.uk/government/news/pharmaceuticalcompany-accused-of-overcharging-nhs [https://perma.cc/4UAL-7BCW]; Press Release, Competition \& Mkts. Auth., CMA Fines Pfizer and Flynn $£ 90$ Million for Drug Price Hike to NHS (Dec. 7, 2016), https://www.gov.uk/government/news/cma-fines-pfizer-and-flynn90-million-for-drug-price-hike-to-nhs [https://perma.cc/FMT4-HR9Y].

228. Dougherty, Jr. et al., supra note 219 , at 90-91. 


\section{The FTC Should Favor Simple Structural Remedies}

Along with establishing presumptions of illegality for competitively suspicious conduct and bringing persistent or otherwise harmful market power, the FTC must adopt effective remedies when it establishes a violation of Section 5. Even clear legal prohibitions on anticompetitive behavior cannot be effective if they are accompanied by weak, inadequate remedies. ${ }^{229}$ Under these circumstances, a company may be allowed to continue its anticompetitive conduct or a market may remain structurally noncompetitive.

To ensure the effectiveness of Section 5, the FTC must commit to simple structural remedies. In cases in which a specific anticompetitive practice is the principal barrier to a competitive market, a conduct remedy - a prohibition on this act-may be sufficient to restore competition. In cases in which the structure of the market is at issue, only a structural remedy is likely to be sufficient. A conduct remedy, in these matters, would typically involve a combination of prohibitions, requirements, and ongoing oversight by the FTC. Conduct remedies are likely to be incomplete and susceptible to evasion in spirit, if not in letter. ${ }^{230}$ In contrast, a structural remedy allows for a one-time fix that, if properly implemented, addresses the problem and removes the need for intrusive regulatory oversight in the future. ${ }^{231}$

The FTC should establish a strong presumption in favor of structural solutions in merger and other matters implicating market structure. In challenging anticompetitive mergers, the FTC should seek to stop mergers outright instead of modify them through divestitures. Divestitures have often failed to preserve competition even from a consumer welfare perspective. $^{232}$ Some recent FTC-mandated divestitures in mergers have failed in spectacular fashion. ${ }^{233}$ Furthermore, these divestitures do nothing

229. See United States v. E.I. Du Pont de Nemours \& Co., 366 U.S. 316, 323 (1961) ("The proper disposition of antitrust cases is obviously of great public importance, and their remedial phase, more often than not, is crucial. For the suit has been a futile exercise if the Government proves a violation but fails to secure a remedy adequate to redress it.").

230. Edward Cavanagh, Antitrust Remedies Revisited, 84 OR. L. REV. 147, 189-90 (2005).

231. Neil W. Averitt, Structural Remedies in Competition Cases Under the Federal Trade Commission Act, 40 ОH. ST. L.J. 781,833 (1979).

232. Staff of the Bureau of Competition of the Fed. Trade Comm'n, A Study of THE COMmission's Divestiture Process (1999), https://www.ftc.gov/sites/default/files/ attachments/merger-review/divestiture.pdf [https://perma.cc/R3BP-XSKA].

233. Brent Kendall \& Peg Brickley, Albertsons to Buy Back 33 Stores It Sold as Part of Merger With Safeway, WALL ST. J. (Nov. 24, 2015, 7:26 PM), https://www.wsj.com/articles/albertsons-to-buy-back-33-stores-it-sold-as-part-of-mergerwith-safeway-1448411193 [https://perma.cc/A62Z-WB7Z]; Brent Kendall \& Jacqueline 
to stop the concentration of private economic and political power. Companies are permitted to grow in size through consolidation, so long as they sell assets in markets in which there is head-to-head competition. In dominant firm cases that seek to address the underlying market structure, the FTC should pursue restructuring remedies that, for example, divide the company into multiple competing entities or separate related lines of business into separate firms.

\section{RESPONDING TO LIKELY OBJECTIONS TO AN EXPANSIVE SECTION 5}

The proposed interpretation of Section 5 represents a break with decades of antitrust thinking and would trigger opposition if adopted. It harkens back to an older tradition of antitrust that had a more comprehensive understanding of corporate power than today's fixation on short-term price and output effects. Dominant corporations certainly prefer the permissive antitrust environment at present and would resist any efforts to strength antitrust doctrine. Industry-funded academics, consultants, and lobbyists who champion lax antitrust policy would likely be another important voice against change. ${ }^{234}$ And even those sympathetic to a more

Palank, How the FTC's Hertz. Antitrust Fix Went Flat, WALL ST. J. (Dec. 8, 2013, 8:03 PM), https://www.wsj.com/articles/SB10001424052702303330204579246281764302824 [https://perma.cc/TGT2-URTR].

234. See, e.g., Eisinger \& Elliott, supra note 153 ("Economists who specialize in antitrust - affiliated with Chicago, Harvard, Princeton, the University of California, Berkeley, and other prestigious universities - reshaped their field through scholarly work showing that mergers create efficiencies of scale that benefit consumers. But they reap their most lucrative paydays by lending their academic authority to mergers their corporate clients propose. Corporate lawyers hire them from Compass Lexecon and half a dozen other firms to sway the government by documenting that a merger won't be 'anticompetitive': in other words, that it won't raise retail prices, stifle innovation, or restrict product offerings. Their optimistic forecasts, though, often turn out to be wrong, and the mergers they champion may be hurting the economy."); David Dayen, Google Gets a Seat on the Trump Transition Team, INTERCEPT (Nov. 15, 2016, 4:08 PM), https://theintercept.com/2016/11/15/google-gets-a-seat-on-the-trump-transition-team/ [https://perma.cc/D7VX-GMF3] ("Joshua Wright has been put in charge of transition efforts at the influential Federal Trade Commission after pulling off the rare revolving-door quadruple-play, moving from Google-supported academic work to government - as an FTC commissioner - back to the Google gravy train and now back to the government.").

Looking beyond particular individuals, the ascendancy of the Chicago School in antitrust can be attributed, in part, to self-interested funding from big business interests:

Chicago's intellectual ascendance also aligned fortuitously with the interests of the increasingly organized business community. Henry Manne, an Antitrust Workshop alum who was a critical entrepreneur in the law and economics movement, found that between 1968 and 1971 it became much easier to raise 
expansive Section 5 may express reservations because of past Congressional backlash against a zealous FTC. At least three arguments are likely to gain traction in public debates.

The proposed interpretation would defuse one common criticism that has been leveled against Section 5 for many years. Some commentators have claimed that Section 5, with its vagueness, creates great uncertainty for businesses. Per this view, corporations and their counsel do not know in advance what type of conduct runs afoul of Section $5 .^{235}$ By establishing a system of presumptions, the interpretation of Section 5 advanced here would greatly diminish legal uncertainty and simplify compliance. The proposed interpretation of Section 5 would have greater clarity than the rule of reason under the Sherman and Clayton Acts. ${ }^{236}$ With a series of relative bright lines, businesses would have much greater legal guidance on permissible conduct than they do, at present, under the open-ended rule of reason and Horizontal Merger Guidelines.

industry money on its behalf: 'At this point, the [corporate] world knew that Chicago economics was the only thing that could possibly save them from an antitrust debacle, and I related it strongly to that. . . . Well, of the eleven [major corporations] I wrote to, within a few weeks I had $\$ 10,000$ from ten of them, and the last $\$ 10,000$ came in a few weeks later.' Similarly, funders of the Airlie House conference, at which Chicago supporters saw themselves as having trounced [the structure-conduct-performance school of antitrust thought], read basically like a list of 1960s Antitrust Division targets: Alcoa, Amoco, Bethlehem Steel, Exxon, General Electric, General Motors, IBM, and so on.

Elizabeth Popp Berman, How Experts Can, and Can't, Change Policy: Economics, Antitrust, and the Linked Evolution of the Academic and Policy Fields 24-25 (Jan. 2017) (unpublished manuscript), https://osf.io/c4bfm/?action=download [https://perma.cc/PF5Y27P9] (footnotes omitted).

235. E.g., James C. Cooper, The Perils of Excessive Discretion: The Elusive Meaning of Unfairness in Section 5 of the FTC Act 33, $52-53$ (Geo. Mason Mercatus Ctr., Working Paper No. 13-20, 2013), http://mercatus.org/sites/default/files/Perils-Excessive-DiscretionSummary.pdf [https://perma.cc/6ZF4-Q7DX] (stating that the ambiguous antitrust provision of the FTC Act has left businesses unsure of "unfair methods of competition" in comparison to legal activities).

236. See Jesse W. Markham, Jr., Sailing A Sea of Doubt: A Critique of the Rule of Reason in U.S. Antitrust Law, 17 FORDHAM J. CORP. \& FIN. L. 591, 623-24 (2012) ("The rule of reason is now 100 years old and the promise of clarification through judicial application has proven to be empty. The rule's purported standard is devoid of substantive content that could guide judges to apply it consistently so that patterns could emerge. Not only has the Court failed to give content to this legal standard, but it has indulged in shifting the standard around in response to the economic theory $d u$ jour.") (footnotes omitted). 


\section{A. Attacking the Proposed Interpretation of Section 5 on Efficiency Grounds Ignores Congressional Intent}

Critics of the proposed interpretation may claim that it would prevent businesses from engaging in efficiency-enhancing conduct. Conduct that enhances efficiency, according to the precepts of neoclassical price theory, would be either prohibited or discouraged under an expansive Section 5, the critics would claim. The result would be higher prices and reduced economic output. According to this view, antitrust would once again be a policy "at war with itself.",237

This objection is wide of the mark and assumes that efficiency is the proper objective of Section 5 and antitrust law generally. To paraphrase a line from an iconic dissent of Justice Holmes, the FTC Act does not enact Mr. Robert Bork's Antitrust Paradox. ${ }^{238}$ Rather, the Congress that enacted the FTC Act had a grand political economic vision that aimed to protect consumers and producers from the overwhelming power of large corporations, preserve businesses' freedom to compete, and defend American political institutions from the power of large businesses. ${ }^{239}$ To criticize the proposed interpretation of Section 5 for reducing economic efficiency is to assume that an ill-defined efficiency goal is the appropriate goal of antitrust. The legislative histories of the antitrust statutes, including the FTC Act, contradict this assumption in no uncertain terms. As the Supreme Court has noted, "[c]itizens and legislators may rightly insist that they are willing to tolerate some loss in economic efficiency in order to deter what they consider morally offensive conduct" and that "efficiency is just one consideration among many." 240

Allocative efficiency is not somehow "neutral" or "apolitical." It seeks to promote a concept of social welfare that takes the existing distribution of resources as given, posits that human behavior is rational and selfish, and calls on the state to enforce property and contractual rights to a maximal degree. ${ }^{241}$ By omitting any consideration of distributional

237. Bork, supra note 165 .

238. Lochner v. New York, 198 U.S. 45, 75 (1905) (Holmes, J., dissenting).

239. See supra part II.A.

240. Cooper Indus., Inc. v. Leatherman Tool Grp., Inc., 532 U.S. 424, 439-40 (2001) (quoting Marc Galanter \& David Luban, Poetic Justice: Punitive Damages and Legal Pluralism, 42 AM. U. L. REV. 1393, 1450 (1993)).

241. John J. Flynn, The Reagan Administration's Antitrust Policy, "Original Intent" and the Legislative History of the Sherman Act, 33 ANTITRUST BULL. 259, 265-67 (1988). Even on neoclassical terms, the efficiency paradigm is deficient because it ignores externalities, a rather major omission at a time of global climate change. Jeffrey L. Harrison, Some Inconvenient Truths About Antitrust Law and Economics 9 (Univ. Fla. Levin Coll. of Law, Legal Studies Research Paper Series, Paper No. 17-1, 2017), 
consequence, this conception of efficiency is heavily skewed in favor of the status quo. ${ }^{242}$ Exposing these assumptions reveals the conservative nature of allocative efficiency.

The proposed presumptions would not dismiss the importance of efficiency in business operations. Under the proposed Section 5, businesses that trigger a presumption of illegality, whether due to a proposed merger or competitively suspect conduct, would have the opportunity to establish business justifications. For example, a horizontal merger that exceeds the threshold of twenty percent would be presumptively illegal. The parties, however, could rebut this presumption by demonstrating that the merger is necessary and the least restrictive way to achieve an operational efficiency. This approach would be an inversion of the current standard in which efficiencies are assumed and anticompetitive harm has to be shown. ${ }^{243}$ Efficiencies would no longer be accepted as a matter of faith in neoclassical economic logic. ${ }^{244}$ They would have to be shown. Given the congressional vision for the FTC Act, this is the appropriate standard.

\section{B. Claiming that Proposed Section 5 Would Create Substantive Inconsistency Between the FTC and the DOJ Disregards Congressional Intent and Existing Antitrust Practice}

Critics of the proposed Section 5 would likely also claim that it would drive a wedge between the statutory authorities of the FTC and those of the DOJ. Proposed Section 5 would give the FTC more sweeping powers than the DOJ. An investigation by the FTC could have a very different result than a comparable investigation by the DOJ. In the context of mergers, this problem may be most acute because the two agencies have divided up the review process by industry. A merger in the chemical industry

https://poseidon01 .ssrn.com/delivery.php?ID=3500170640030841130670980990871111190 97014088087016004031104071030089006066070008030032012051099111045001108075 00808511907502905807301705206502006801111802402406409008802903212306611611 $8090028120117082072076093066073089123024021113079065119111085124070 \& E X T=$ pdf [https://perma.cc/WB9V-M9V3].

242. Herbert Hovenkamp, Antitrust Policy After Chicago, 84 Мich. L. Rev. 213, 215 (1985).

243. See, e.g., United States v. Microsoft Corp., 253 F.3d 34, 58 (D.C. Cir. 2001) ("[T]o be condemned as exclusionary, a monopolist's act must have an 'anticompetitive effect.' That is, it must harm the competitive process and thereby harm consumers. In contrast, harm to one or more competitors will not suffice.").

244. See Eleanor M. Fox, The Efficiency Paradox, in How THE CHICAGO SCHOOL Overshot THE MARK 77, 81-86 (Robert Pitofsky ed., 2008) (observing how conservative economic assumptions have driven Supreme Court's antitrust rulings). 
(traditionally reviewed by the FTC) would be subject to different legal standards than a merger in the airline industry (traditionally reviewed by the DOJ).

The possibility of divergences would not undercut the case for a more expansive Section 5. Some differences could be resolved. For example, the DOJ could, through guidelines and litigation, seek to establish similar or identical merger standards to the FTC under the Clayton Act, which, like the FTC Act, is an incipiency statute.

Even when differences would arise, they would reflect a conscious choice on the part of Congress. When creating the FTC, Congress granted the FTC more expansive statutory authority than the DOJ. The FTC was established against the backdrop of the Sherman Act being enforced by the DOJ and private parties. The Sherman Act had been in existence for twenty-five years when the FTC came into being. Congress intended for the FTC Act to reach a larger set of business conduct than the Sherman Act, which was viewed as not being up to the challenge of controlling the corporate giants of the day. ${ }^{245}$ For example, the incipiency standard of the FTC Act was meant to correct the overly permissive standard of the Sherman Act. ${ }^{246}$ The broader reach of Section 5 was a conscious choice by Congress. Demanding that the DOJ and the FTC apply their powers in an identical fashion overlooks this Congressional decision.

The divergence criticism ignores current antitrust practice and assumes an inter-agency harmony that does not exist at present. At any given time, the DOJ and FTC have different leadership and can be expected to diverge at least on the margins. For example, the FTC has brought many more Section 2 actions than the DOJ since 2009, suggesting that the former views monopolization as a higher priority than the latter. ${ }^{247}$ And during the George W. Bush administration, the two agencies clashed in public, most notably over the meaning of Section $2 .{ }^{248}$ These are just some of the

245. See supra Part II.B.

246. See supra Part II.B.

247. The DOJ has brought two Section 2 cases during the Obama years: United States v. United Cont'1 Holdings, Inc., No. 2:15-cv-07992 (D.N.J. filed Nov. 10, 2015); United States v. United Reg'1 Health Care Sys., No. 7:11-cv-00030 (N.D. Tex. filed Feb. 25, 2011). The FTC has brought at least seven Section 2 cases: McWane, Inc. v. FTC, 783 F.3d 814 (11th Cir. 2015); FTC v. Cardinal Health, Inc., No. 15-cv-3031 (S.D.N.Y. filed Apr. 20, 2015); FTC v. AbbVie Inc., 107 F. Supp. 3d 428, 430 (E.D. Pa. 2015); In re IDEXX Labs., Inc., 155 F.T.C. 241 (2013); In re Pool Corp., F.T.C. No. 101-0115, 2012 WL 159752 (Jan. 10, 2012); In re Intel Corp., 150 F.T.C. 420 (2010); In re Transitions Optical, Inc., 149 F.T.C. 1281 (2010).

248. See Press Release, Fed. Trade Comm'n, FTC Commissioners React to Department of Justice Report, Competition and Monopoly: Single-Firm Conduct Under Section 2 of the Sherman Act (Sept. 8, 2008), https://www.ftc.gov/news-events/press-releases/2008/09/ftccommissioners-react-department-justice-report-competition-and [https://perma.cc/KPC3- 
differences between two agencies.

The federal judiciary adds another thick layer of doctrinal inconsistency today. In a legal system made up of hundreds of district and appellate judges at the federal system, legal harmony is a futile aspiration. The existing substantive law in antitrust, which elevates open-ended standards over rules, guarantees a legal patchwork. ${ }^{249}$ For instance, a merger challenge heard by a conservative judge is likely to fare differently than a merger challenge before a progressive judge. At present, certain circuits are seen as more sympathetic to particular claims than others. ${ }^{250}$ The Supreme Court could, of course, establish legal standardization. Yet, in light of the relatively few cases heard by the Supreme Court in a given year, harmonization of legal standards is improbable and, at best, likely to happen after an extended period of conflicting or inconsistent standards in the lower courts.

\section{Recognizing the Threat of Adverse Congressional Action Does Not Compel Continued Adherence to the Antitrust Status Quo}

Among those sympathetic to an expansive Section 5, some are likely to express reservations about its political feasibility. History certainly lends support to this concern. Congress has been hostile to an activist FTC in the past and could be expected to move to rein in any activism. In the 1970s, the FTC zealously pursued its antitrust and consumer protection missions. ${ }^{251}$ This period of aggressive enforcement and rulemaking triggered a powerful backlash from corporate America. ${ }^{252}$ The Washington Post condemned the Commission as the "National Nanny" in a stinging editorial. ${ }^{253}$ This period of zeal ended poorly for the FTC. Congress

74ZY] (stating that the Department of Justice Report on Section 2 "is chiefly concerned with firms that enjoy monopoly or near-monopoly power, and prescribes a legal regime that places these firms' interests ahead of those of consumers").

249. Stucke, supra note 141, at 1432-33.

250. As an example of the divergence, the Third and Ninth Circuits treat loyalty rebates by dominant firms differently. Compare LePage's Inc. v. 3M, 324 F.3d 141 (3d Cir. 2003) (adopting a more plaintiff-friendly standard) with Cascade Health Sols. v. PeaceHealth, 515 F.3d 883, 905-06 (9th Cir. 2007) (applying standard favoring defendants).

251. William J. Baer, Where to From Here: Reflection on the Recent Saga of the Federal Trade Commission, 39 OKLA. L. REv. 51, 53 (1986).

252. Michael Pertschuk, Comm'r, Fed. Trade Comm'n, Lecture at the University of California Berkeley School of Business Administration: Stoning the National Nanny: Congress and the FTC in the Late 70's (Nov. 11, 1981), https://www.ftc.gov/ system/files/documents/public_statements/688981/19811104_pertschuk_lecture_iii_stoning _the_national_nanny-_congress_and_the_ftc_in_the_late_70s.pdf [https://perma.cc/P7UALF88].

253. Editorial, The FTC as National Nanny, WASH. Post (Mar. 1, 1978), 
asserted new power over the agency and imposed additional procedural conditions on the use of its consumer protection authority. ${ }^{254}$

This fear of a political backlash from business and Congress may be the strongest line of criticism of an expansive Section 5. Corporations pour money into Congressional campaigns to ensure that their interests are represented and advanced. Although the FTC has been averse to policy activism or innovation for decades, the House has tried to limit the FTC's authority to challenge mergers under Section 5 , in the name of creating harmony between the FTC and the DOJ. ${ }^{255}$

The recent experience of another federal agency is instructive. Congressional Republicans, with the support of some Democrats, have been trying to hobble the Consumer Financial Protection Bureau ("CFPB"). ${ }^{256}$ The CFPB is seen as aggressively pursuing its statutory mission, bringing a wide range of enforcement actions and writing a number of rules to regulate consumer finance markets. ${ }^{257}$ In light of its vigor, the opposition from Congress does not come as a surprise. Even under more favorable political circumstances, an FTC that seeks to breathe life into Section 5 is certain to invite comparable Congressional opposition.

The probable reaction from many ideologically or financially captured members of Congress should not be underestimated, let alone ignored. Corporate interests and their Congressional allies would seek to curtail any Section 5 expansions. The FTC is a creation of Congress and so must answer to Congress. Congress can undertake a range of actions to limit the FTC's day-to-day ability to function and its statutory power. At an extreme, Congress could repeal the FTC Act and shut down the FTC entirely. The risks to the FTC's future would include various existential threats and should not be brushed aside. Undertaking a reinterpretation of Section 5 without an awareness of political dynamics on Capitol Hill would

https://www.washingtonpost.com/archive/politics/1978/03/01/the-ftc-as-nationalnanny/69f778f5-8407-4df0-b0e9-7f1f8e826b3b/ [https://perma.cc/632F-DTQL].

254. Baer, supra note 251, at 54.

255. Press Release, House of Representatives Judiciary Comm., Regulatory Reform Subcommittee to Hold Hearing on the SMARTER Act (June 12, 2015), https://judiciary.house.gov/press-release/regulatory-reform-subcommittee-to-hold-hearingon-the-smarter-act/ [https://perma.cc/Z95A-XRPG].

256. See, e.g., Victoria Finkle, House Republicans Clash With Consumer Protection Unit Chief, N.Y. TIMES: DEALBoOK (Mar. 16, 2016), http://www.nytimes.com/ 2016/03/17/business/dealbook/house-republicans-clash-with-consumer-protection-unitchief.html [https://perma.cc/PK9K-E99P] (describing criticism levelled at the bureau by Congressional Republicans and some Democrats).

257. See, e.g., David Dayen, CFPB Turns 5 - and Financial Scammers Aren't Celebrating, FISCAL TIMES (July 22, 2016), http://www.thefiscaltimes.com/Columns/ 2016/07/22/CFPB-Turns-5-and-Financial-Scammers-Aren-t-Celebrating [https://perma.cc/9H6A-FXSZ]. 
be a grave mistake.

Yet, these political risks do not call for resignation and indefinite inaction. Just as the power of corporate interests in American society cannot be dismissed, the changing political dynamics in the United States should also not be discounted. Forty years of income stagnation and a dramatic rise in inequality have brought the merits of existing political economic arrangements, including weakened antitrust, ${ }^{258}$ into doubt. ${ }^{259}$ At a 2016 Senate antitrust oversight hearing, Democrats and Republicans raised concern over inadequate antitrust enforcement. ${ }^{260}$ Even Senator Mike Lee, a hardline conservative from Utah, questioned the effectiveness of current merger policy. ${ }^{261}$ Senator Bernie Sanders, a self-described democratic socialist, championed economic populism and a revival of the New Deal and won twenty-two states in his campaign to be the Democratic nominee for president-a campaign that seemed quixotic just a year ago. ${ }^{262}$ The Democratic Party now has a faction that seeks to challenge the status quo across a number of areas, ${ }^{263}$ including antitrust. ${ }^{264}$ Public concerns about the power of corporations are being reported in the mainstream press again, after years of neglect. ${ }^{265}$ Even President Trump has raised concerns about corporate mergers and monopolies, ${ }^{266}$ though it seems unlikely he will act in any systematic fashion. ${ }^{267}$

258. See supra notes 1 and 2.

259. Jedediah Purdy, A World to Make: Eleven Theses for the Bernie Sanders Generation, DisSENT MAG. (Apr. 21, 2016), https://www.dissentmagazine.org/ online_articles/eleven-theses-bernie-sanders-generation-democratic-socialism [https://perma.cc/WFN8-N8C3].

260. Cooper, supra note 2.

261. Cooper, supra note 2.

262. Kurtis Lee, Bernie Sanders Signals He's Winding Down His Campaign, But Doesn't Quit, L.A. TIMES (June 16, 2016), http://www latimes.com/politics/la-na-pol-berniesanders-campaign-20160616-snap-story.html [https://perma.cc/KS5G-VM9N].

263. E.g., Adam Green, How the Elizabeth Warren Wing Shifted Tuesday's Democratic Debate, HuFFINGTON Post, http://www.huffingtonpost.com/adam-green/how-the-elizabethwarren-_b_8270958.html [https://perma.cc/D6QD-6YXJ] (last updated Oct. 9, 2016) (stating that Democrats shifted the focus to economic populist issues during the 2016 presidential debates).

264. Warren, supra note 3.

265. See supra notes 1 and 2 .

266. Michael J. de la Merced \& Cecilia Kang, Future of Big Mergers Under Trump? Like Much Else, It's Unclear, N.Y. Times: DeAlBook (Nov. 10, 2016), http://www.nytimes.com/2016/11/11/business/dealbook/future-of-big-mergers-under-trumplike-much-else-its-unclear.html?_r=0 [https://perma.cc/FYR7-MERP].

267. See Brian Fung, Trump Names Maureen Ohlhausen as Acting FTC Chairwoman, WASH. POST (Jan. 25, 2017), https://www.washingtonpost.com/news/the-switch/wp/ 2017/01/25/trump-names-maureen-ohlhausen-as-acting-ftc-chairwoman/?utm_ term $=.738 \mathrm{c} 83 \mathrm{e} 5845 \mathrm{~d}$ [https://perma.cc/JRF7-BDSQ] (describing Ohlhausen's skepticism toward FTC enforcement actions and FCC's net neutrality rules). 
The Federal Communications Commission's ("FCC") rule to impose non-discrimination and no-blocking requirements on broadband providers (popularly known as "net neutrality") ${ }^{268}$ offers lessons on how the FTC could proceed. The FCC's campaign to establish net neutrality challenged some of the most powerful corporations in the country and involved judicial setbacks and multiple policy reversals. ${ }^{269}$

The FCC succeeded in large measure because of the political support for net neutrality. Activists and advocates effectively conveyed the importance of net neutrality to the broader population and tailored their message to different communities. ${ }^{270}$ Businesses that stood to lose from the exclusionary practices of broadband providers also played an important role in championing net neutrality. ${ }^{271}$ Furthermore, the FCC enjoyed key support in Washington, with President Obama $^{272}$ and a number of Representatives and Senators ${ }^{273}$ calling for strong net neutrality rules. ${ }^{274}$ The groundswell of public support, reflected in the 4 million mostly supportive comments that were submitted to the $\mathrm{FCC},{ }^{275}$ and pressure from high-profile political figures persuaded the FCC to take a strong approach and surely steeled its political will.

Political and public support for a broad Section 5 is essential. If the FTC were to proceed without strong public support and backing from the White House and progressive factions in Congress, it would face long odds

268. In re Protecting and Promoting the Open Internet, 30 FCC Rcd. 5601 (2015).

269. See, e.g., Verizon v. FCC, 740 F.3d 623, 659 (D.C. Cir. 2014) (vacating the FCC's 2010 net neutrality rules); Comcast Corp. v. FCC, 600 F.3d 642, 661 (D.C. Cir. 2010) (vacating the FCC's regulation of Comcast's broadband network).

270. What Worked in the Fight for Net Neutrality, GetTysburg Project (Aug. 2015) http://gettysburgproject.org/net-neutrality [https://perma.cc/Q8XH-AF6X].

271. Id.

272. Inae Oh, Obama Just Announced His Full Support to Preserve Net Neutrality, Mother JONES (Nov. 10, 2014, 12:05 PM), http://www.motherjones.com/ mojo/2014/11/obama-net-neutrality [https://perma.cc/8LJY-6YN5].

273. E.g., Press Release, Office of Senator Ron Wyden, Senators Urge FCC to Promote Net Neutrality, Reverse Proposal to Create Internet Toll Lanes (May 9, 2014), https://www.wyden.senate.gov/news/press-releases/senators-urge-fcc-to-promote-netneutrality-reverse-proposal-to-create-internet-toll-lanes [https://perma.cc/KW2M-PZRA]; Julian Hattem, Franken: Net Neutrality Is "First Amendment Issue of Our Time", THE HILL (July 8, 2014, 4:08 PM), http://thehill.com/policy/technology/211607-franken-netneutrality-is-first-amendment-issue-of-our-time [https://perma.cc/JD3T-D8G8].

274. Edward Wyatt, Obama Asks F.C.C. to Adopt Tough Net Neutrality Rules, N.Y. TimeS (Nov. 10, 2014), http://www.nytimes.com/2014/11/11/technology/obama-netneutrality-fcc.html [https://perma.cc/8ZJ4-JLWB].

275. Todd Shields, It Took Four Million E-Mails to Get the FCC to Set Net-Neutrality Rules, BloOMBERG (Feb. 3, 2015, 1:55 PM), http://www.bloomberg.com/news/articles/ 2015-02-03/a-rant-and-4-million-e-mails-later-fcc-to-set-web-traffic-rules [https://perma.cc/HTV4-4Q2V]. 
of success. One agency alone, regardless of its determination, cannot stand up to the power of big business.

If, however, the FTC can draw on and reinforce public support and count on the White House and Congress to champion its efforts, it has a much better chance of overcoming powerful opposition. Activists and advocates who support open, competitive markets would have to play a principal role in explaining the significance of Section 5 to the public. As the net neutrality episode shows, skilled advocates can explain and demonstrate the significance of arcane issues such as telecommunications policy to a lay audience. Antitrust law, which once inspired popular movements ${ }^{276}$ can certainly be translated into accessible and compelling language. ${ }^{277}$ Moreover, businesses that are threatened by dominant incumbents would also have to be engaged and mobilized to challenge the power and narrative of the anti-Section 5 monopolists and oligopolists.

While the near term is bleak on antitrust, among other areas, a future FTC may be in a position to restore the progressive-populist foundation of antitrust law. Under the leadership of the conservative Maureen Ohlhausen, the FTC appears poised for at least a few more years of dormancy. ${ }^{278}$ But looking past the immediate future and to subsequent leadership, the FTC may have an opportunity to make antitrust a force against concentrated private power and for ordinary Americans.

An antitrust revival through Section 5 would not be easy and would require determination and patience on the part of those inside and outside government who believe in a reinvigorated Section 5. And success, even under the best circumstances, would not be guaranteed. Yet, popular demand for aggressive anti-monopoly action seems to be growing. Given economic realities, the growing discontent in the country in general does not appear poised to subside any time soon. ${ }^{279}$ And the success of the FCC's net neutrality rules show that there is a way forward for the FTC

276. Richard Hofstadter, What Happened to the Antitrust Movement?, in THE PARANOID STYLE In AMERICAN POLITICS AND OTHER EsSAYs 188, 189 (1965).

277. For example, Senator John Sherman eschewed the arcane language of economics and declared:

[If] we will not endure a king as a political power we should not endure a king over the production, transportation, and sale of any of the necessaries of life. If we would not submit to an emperor we should not submit to an autocrat of trade, with power to prevent competition and to fix the price of any commodity.

21 CONG. REC. 2457 (1890).

278. Fung, supra note 267.

279. Thomas Piketty, We Must Rethink Globalization, or Trumpism Will Prevail, GUARDIAN (Nov. 16, 2016, 6:00 AM), https://www.theguardian.com/commentisfree/ 2016/nov/16/globalization-trump-inequality-thomas-piketty [https://perma.cc/6EYHCENA]. 
even in the face of fierce corporate opposition. The FTC's defeats in the late 1970s do not compel another generation of agency quiescence.

\section{CONCLUSION}

After decades of practical exile from popular discussion, monopoly and oligopoly are topics of public debate again. Politicians and commentators from across the ideological spectrum acknowledge that there is a lack of competition across the U.S. economy and that the harms from this noncompetitive industrial structure are very real. Importantly, many observers have recognized that the current industrial structure in the United States was the product of a deliberate policy choice. Beginning in the late 1970s and accelerating in the 1980s under the Reagan administration, antitrust officials in the executive branch and federal judges reinterpreted these laws to focus narrowly on the neoclassical economic concept of allocative efficiency and adopted legal standards favorable to powerful corporate defendants. This stealth counterrevolution reinterpreted laws that Congress had enacted to check the myriad harms from concentrated corporate power.

Although any judicial efforts to reinterpret the antitrust laws in accord with Congress's original vision are uncertain and likely to take years, if not decades, the Federal Trade Commission under progressive leadership has the power to restore progressive-populist antitrust in the more immediate future. Under contemporary administrative law and Congressional delegation of policymaking power, the Federal Trade Commission has broad authority to resurrect antitrust law under Section 5 of the FTC Act. In enacting this statute, Congress wanted the FTC to police "unfair methods of competition" that injure consumers and smaller sellers, prevent competitors from competing on the merits, and allow large corporations to dominate our political system. Congress intended the FTC's antitrust authority to encompass more than the prohibitions in the Sherman and Clayton Acts and to nip anticompetitive problems in the embryonic stage before they harmed markets and society.

For more than thirty years, the FTC has been a proponent of an antitrust that stresses the primacy of economic efficiency. The FTC's Section 5 Statement indicated that the Commission would use its Section 5 authority to advance "consumer welfare" and apply the rule of reason framework. In articulating this narrow interpretation of Section 5, the FTC contradicted Congress's broader political economic vision in 1914, which sought to prevent not only short-term injuries to consumers but also exclusionary practices by large businesses and the accumulation of private political power. Furthermore, the FTC adopted the complicated rule of 
reason that arguably cannot even protect consumers, let alone advance the progressive-populist philosophy underpinning Section 5.

Despite being a champion of the efficiency paradigm since 1981, the FTC in the future could still change course and be true to Congressional intent in creating the agency in 1914. In setting out an interpretation of Section 5, whether through enforcement actions or rulemakings, the FTC should anchor Section 5 in the expansive political economic vision of Congress. In enacting the Federal Trade Commission Act to supplement the Sherman and Clayton Acts, Congress sought to prevent three principal harms from concentrated economic power: wealth transfers exacted by monopolies, oligopolies, and cartels, privately-erected barriers to competition, and accumulation of economic and political power in corporate hands. To advance Congress's antitrust vision and aim for the FTC Act to be a prophylactic statute, the FTC should adopt presumptions of illegality for a variety of competitively suspicious conduct, challenge durable or otherwise significantly harmful monopolies, and support simple structural remedies. In adopting the proposed interpretation of Section 5, the FTC would be true to the vision Congress had in creating the Commission a century earlier and respond to growing popular and political demands to tackle the curse of pervasive monopoly and oligopoly in the economy. 